\title{
Autopia as new perceptual regime: mobilized gaze and architectural design
}

\author{
Marianna Charitonidou ${ }^{1,2,3^{*}}$ (])
}

\begin{abstract}
The automobile has reshaped our conceptions of space and our modes of accessing and penetrating the urban and non-urban territory in multiple ways, revolutionizing how architects perceive the city and contributing significantly to the transformation of the relationship between architecture and the city. Despite the fact that many architects and architectural critics and theorists have been attracted to automobile vision, in the field of history and theory of architecture and urban design, many questions concerning the impact of the automobile on our perception of the city and its territory have not yet been explored in depth. This is surprising when one considers that no other single factor changed the city so drastically during the twentieth century as the pervasive presence of the automobile. The article examines three different cases of architects—John Lautner, Alison and Peter Smithson, and Aldo Rossi—who tried to construct new visual regimes in photography from the car. The main objective is to present how new visual regimes in photography from the car informed in various ways the visual attitudes in their designs of buildings. The interexchange between the ways of capturing the views from the car and the formation of new design methods can explain the necessity to establish a new theoretical framework offering the possibility to historians of architecture and urban design to address in a sharp and concrete way the reciprocal relation between automobile vision and design approaches.
\end{abstract}

Keywords: Automobile vision, Sequentiality, Snapshot aesthetics, John Lautner, Alison and Peter Smithson, Aldo Rossi, Semi-directedness, Photography

\section{Introduction: Relating the automobile vision with the design approaches}

This article aims to untie the specificity of car travel as an apparatus or dispositif of perceiving urban and non-urban landscapes, on the one hand, and to explore the relationship between the process of taking photographs from the car and the emergence of new perceptual regimes in the field of architecture and urban design, on the other hand. Special attention is paid to the fact that " $[\mathrm{t}]$ he concept of dispositif is based on the intention to treat heterogeneous systems-object, subject, language and so on-, assuming that the systems are composed of interacting forces

\footnotetext{
*Correspondence: mchariton@ethz.ch

${ }^{1}$ Chair of the History and Theory of Urban Design, Institute for the History and Theory of Architecture (gta), Department of Architecture, ETH Zürich, Stefano-Franscini-Platz 5, 8093 Zurich, Switzerland

Full list of author information is available at the end of the article
}

that are in a continuous state of becoming, 'always off balance, to borrow Gilles Deleuze's words" (Charitonidou 2020). Here, the concept of apparatus or dispositif is used as Michel Foucault understands it, taking also into account how Gilles Deleuze defines it:

But what is a dispositif? In the first instance it is a tangle, a multilinear ensemble. It is composed of lines, each having a different nature. And the lines in the apparatus [dispositif] do not outline or surround systems which are each homogeneous in their own right, object, subject, language, and so on, but follow directions, trace balances which are always of balance, now drawing together and then distancing themselves from one another. Each line is broken and subject to changes in direction, bifurcating and forked, and subject to 'drifting.' Visible objects, affirmations which can be formulated, forces exercised 
and subjects in position are like vectors and tensors. (Deleuze 1992, p. 159)

Foucault remarked regarding the concept of apparatus or dispositif:

What I'm trying to pick out with this term is, firstly, a thoroughly heterogeneous ensemble consisting of discourses, institutions, architectural forms, regulatory decisions, laws, administrative measures, scientific statements, philosophical, moral and philanthropic propositions-in short, the said as much as the unsaid. Such are the elements of the apparatus [dispositif]. The apparatus [dispositif] itself is the system of relations that can be established between these elements. Secondly, what I am trying to identify in this apparatus [dispositif] is precisely the nature of the connection that can exist between these heterogeneous elements (Foucault 1980, p. 194, 195).

The article also intends to render explicit how the generalised use of the car is related to the formation of new representational regimes in architecture and urban design, including means such as photography, film, new modes of visual mapping and particular diagrams. Telling regarding the significance of car travel for the reconfiguration of our perception of the city is Reyner Banham's following remark, in Los Angeles: The Architecture of Four Ecologies: "like earlier generations of English intellectuals who taught themselves Italian in order to read Dante in the original, I learned to drive in order to read Los Angeles in the original" (Banham 2009, p. 5). Two films that aimed to address this epistemological shift mentioned above are Kevin Lynch's "View from The Road" released in 1965, and "Reyner Banham Loves Los Angeles", which was released in 1972 and was a BBC Films production. Banham, used the term 'autopia' in the title of the fourth chapter: of Los Angeles: The Architecture of Four Ecologies: "Ecology IV: Autopia" (Banham 2009, p. 195). Despite the fact that Banham did neither define the term nor use it again in the book, reading the chapter one can understand that Banham perceived 'autopia' as "a coherent state of mind, a complete way of life, the fourth ecology of the Angeleno" (Banham 2009, p. 195). More recently, Gabrielle Esperdy used the same term in the title of American Autopia An Intellectual History of the American Roadside at Midcentury. Esperdy refers to the founding of the Autopia Motor Court in 1929 by Carl F. Schader, reminding us that it became fashionable and commonplace a decade later with the opening of Disneyland, which triggered a shift in the meaning of the term (Esperdy 2019). It was then that certain descriptions of Los Angeles as 'autopia' started becoming a commonplace in the pages of Los Angeles Times. Much later, in a 1960 editorial, one encounters more straight forward expressions as "in the autopia known as Los Angeles", for instance (Signals That Think as Well as Blink 1960). The term 'autopia' was also used by Margaret Lawther for her "autopia series" (Terranova 2014).

Despite the fact that architects produced both movies and photographs from the car, the article focuses on the investigation of photography because it departs from the conviction that photography from the car has established a new form of proximity between the passengers that travel in the same car, on the one hand, and between the passengers and the territory, on the other hand. What I argue is that the means par excellence for capturing this new proximity is photography and not movies. Departing from the writings of Donald Appleyard, Kevin Lynch, John Myer, Reyner Banham, Robert Venturi and Denise Scott Brown-but also from John Lautner, Alison and Peter Smithson, Denise Scott Brown and Aldo Rossi's interest in taking photographs from the car-the article intends to establish a broader framework for tackling the issues related to the impact of the automobile on architectural and urban thought. ${ }^{1}$

In the second half of the twentieth century, architects became increasingly aware of the impact of the car. Two books in which this becomes evident are Reyner Banham's seminal book entitled Los Angeles: The Architecture of Four Ecologies, which placed the car at the centre, and Alison Smithson's much less known $A S$ in DS: $A n$ Eye on the Road. The latter refers to "a new kind of freedom offered by the car" (Smithson 1983, p. 3), as well as to "the new sensibility resulting from the moving view of landscape" (Smithson 1983, p. 47). The emergence of this new kind of freedom thanks to the automobile to which Alison Smithson refered in the aforementioned book was related to the spontaneity and freedom concerning the ways in which one can penetrate the territory when travelling by car. In contrast with travelling by train, in the case of which the trajectory is pre-determined, during car travelling one is free to choose their own trajectory. This freedom of penetrating the territory according to one's own desire goes hand in hand with the reinvention of how one sees the territory. This becomes evident in Alison Smithson's insistence about the necessity to "generate a rethinking of the many basic assumptions related to our 'inherited' way of seeing landscape and towns" and to establish "a fresh understanding of what sort of places we wish to build towards" (Smithson 1983, p. 27).

\footnotetext{
${ }^{1}$ For an overview of the impact of the car on the the way we perceive architecture and the city see the exhibition "The View from the Car: Autopia as a New Perceptual Regime" curated by Dr. ir. Marianna Charitonidou in collaboration with Fredi Fischli and Niels Olsen at to be held at Baubibliothek ETH Zurich from 15 September to 15 October 2021. Websites: https://viewfromca rexhibition.gta.arch.ethz.ch, https://viewfromcar.gta.arch.ethz.ch, https:// www.gta.arch.ethz.ch/exhibitions/the-view-from-the-car.
} 
John Lautner, Alison and Peter Smithson, and Aldo Rossi used to take many photographs from the car during their travels. Relating their approaches while taking photographs from the car with their architectural design methods, one can discern how the practice of taking photographs from the car can function as a means of perceiving urban and non-urban landscapes.

\section{The semi-directedness of the architects' gaze and photography from the car}

The architects' gaze could be characterized as semidirected in the sense that they are open to welcoming the newness and spontaneity related to the act of encountering landscapes while travelling by car. A characteristic of the architects' gaze while travelling by car that facilitates the semi-directedness mentioned above is its tendency to establish a new kind of social contact, which Alison Smithson, in AS in DS: An Eye on the Road, described as "social contact by implication" (Smithson 1983, p. 23). This new kind of social contact is related to the new perceptual regime that emerged thanks to the generalised use of the automobile and the fact that the car passengers are, in a sense, semi-disconnected from their context thanks to their possibility to take distance from the noise and the outdoor conditions in general. British sociologist John Urry used the term 'gaze' in The Tourist Gaze (Urry 1990, 2007; Urry and Larsen 2011; Perkins 2001), where he argued that our desires to visit places and the way we experience those places are not simply individual and autonomous but are socially organised. This brings to mind Alison Smithson's concern, in AS in DS: An Eye on the Road, about the impact of mobility on our social patterns and social needs. Urry's point of departure is that there is an important visual dimension in our experience of places.

The view from the car influenced architects in the sense that it helped them discover new ways of perceiving the urban landscape, and new ways of penetrating it. The architects, in the framework of their endeavour to capture the concreteness of these new ways of perceiving and penetrating urban landscape, used means such as photography, film, mapping methods and diagrams. To understand better these modes of representation, we could relate them to Charles Sanders Peirce's tripartite distinction "between symbolic, iconic, and indexical signs[, taking into account that] [a]ccording to his theory, in the case of indexical signs, the link between the representamen and its object may only be inferred" (Charitonidou 2021). Additionally, it would be thought-provoking to relate the "semi-directedness" that characterises the view from the car to Jae Emerling's following remark, in Photography: History and Theory, regarding the status of photography in relation to Peirce's aforementioned tripartite model of interpretation:
An index is a type of sign that is created by cause and effect. In its simplest form, we could say that smoke is an index of fire or a footprint is an index of whatever left it. Within photographic discourse, the index is wielded as a guarantor of a material connection between the image and reality. But a photograph is neither automatic nor is it only indexical. Indexicality may be a condition of photography, but a photograph is certainly iconic and symbolic as well (Emerling 2013, p. 10).

This hybrid status of photography that is highlighted by Emerling can help us better grasp the semi-directedness of the act of taking photographs while travelling by car. Thanks to this semi-directedness, the experience of viewing an urban or non-urban landscape from the car acquires a specific status that has to do with its capacity to enhance a unique mode of concentration, which has been described in different ways by various thinkers. I could refer, for instance, to Iain Borden's remark that the "speed changes how objects appear to us, and how we view these objects [...] [heightening] our sense of these experiences" (Borden 2013, p. 80; Virilio 1995, 1998). This reference to a heightening of our sense thanks to impact of speed on one's perception brings to mind Reyner Banham's position claiming that motorway driving provokes a "high level of attentiveness":

If motorway driving anywhere calls for a high level of attentiveness, the extreme concentration required in Los Angeles seems to bring on a state of heightened awareness that some locals find mystical (Banham 2009, p. 196, 197).

Banham also related this heightening of the level of attentiveness characterising the view from the car to the fact that one while driving is requested to adopt "an open but decisive attitude to the placing of the car on the roadsurface, a constant stream of decisions that it would be fashionable to describe as 'existential' or even 'situational' but would be better to regard simply as a higher form of pragmatism" (Banham 2009).

\section{Juxtaposing film and photography vis-à-vis sequentiality and seriality: between documentary and stimulatory value}

The intention of the architects to capture the automobile vision and to incorporate it within architectural design practice led to their encounter with various methodological questions. Two worth-noting methodological questions to which the architects tried to respond are the following: firstly, which are the most efficient tools for transferring the vision from car to the design approach? Secondly, which is the most convenient way 
of representing the seriality and the sequentiality characterizing the vision from the car? Despite the fact that seriality and sequentiality do not characterise only the view from the car, but also any kind of mobilized gaze, including that when one walks, there are certain aspects that are specific to the gaze while travelling by car. A main difference between the gaze related to car travelling and that related to pedestrian movement has to do with the relation to temporality and memory. In the case of car travelling, speed offers the possibility to juxtapose visual memories in a more immediate way, which has to do with short-term memory. A concept that can help us comprehend the sequential and temporal dimensions related to the act of taking photographs from the car is that of "afterimage", which, as Joan Ramon Resina argues, "does not suggest that one transcends and leaves behind the imaginary[, claiming that] [ $t$ ] he image is retained, but is now temporalized, unstable, complex image brimming with history of its production" (Joan Ramon Resina cited in West Brett 2016, p. 99).

Denise Scott Brown remarked, in "Learning from Pop", an essay originally published in Casabella in 1971, regarding the interrogation whether photography or film is more relevant for capturing the 'snapshot aesthetics' related to the view from the car: "New analytic techniques must use film and videotape to convey the dynamism of sign architecture and the sequential experience of vast landscapes." (Scott Brown 1984; Stierli 2013, p. 151). Scott Brown believed that only film was compatible with the desire to capture the dynamic development of cities. Despite several efforts that have been made to search means that are between film and photography, such as the so-called 'protofilmic sequences', there are still certain characteristics of photography, such as its artefactual value and its capacity to capture experience despite the fact that it is static compared to film, which cannot be captured by other means. Robert Venturi, Denise Scott Brown, and Steven Izenour placed particular emphasis on the use of 'protofilmic sequences' because they thought that they are efficient for conveying the sequentiality and seriality characterizing the view from the car, and for capturing "the unmediated juxtaposition of fragments of reality" (Stierli 2013, p. 42). However, what I argue here is that 'protofilmic sequences', despite the fact that they combine characteristics of both photography and film, do not have the capacity of photographs as far as their artefactual value and their use in the construction of rhetorical regimes by the architects are concerned. In contrast with Scott Brown's disapproval of photography, in "Learning from Pop", what I argue here is that photography as a means of capturing views from the car is characterised by a capacity that cannot be replaced by the act of filming. John Lautner, Alison and
Peter Smithson, and Aldo Rossi were confronted with the methodological question of capturing the views from the car and the ways in which they responded to this question is telling regarding their understanding of the role of photography for the construction of rhetorical regimes.

Two aspects of photography as a means of representation that are useful for responding to the dilemma whether photography or film is more relevant for capturing the 'snapshot aesthetics' related to the view from the car are, firstly, the immediacy of the very moment that one decides to take a photograph, and, secondly, the fragmentary character that characterises the sequences that one can identify when they try to assemble retrospectively a sequence of successive visual impressions during a trajectory by car. To understand the immediacy of photography, we should take into consideration the fact that, when someone decides to take a photograph of a specific fragment of the urban landscape attracting their attention, they construct in their mind the way that this fragment of reality will be interpreted or even aestheticized at a later stage, when the real experience of the urban landscape will have finished. For this reason, their decision to take a specific photograph and to choose a specific fragment of reality among other goes hand in hand with the construction of a fiction of how this image will be interpreted and experienced. Thanks to their capacity to construct fictions, photographs, when detached from the very moment of their genesis, are capable of provoking particular feelings and thoughts. Photography is from the beginning interpretation through selection and contributes to the construction of a fiction in the sense that it propels a world that is not yet there. The fiction to which I refer concerns the capacity of photography as a means of representation to illuminate the most significant, for the photographer, characteristics of the urban landscape in front of which they were the moment they took the photograph.

The fact that the construction of this fiction is very present the moment of taking a photograph makes the act of photo-shooting an interpretative mechanism, and an apparatus of selection of the most significant characteristics of an urban landscape. In a very selective way, moments are isolated and selected and function as a sort of pars pro toto of the bigger landscape both in its morphological and experiential characteristics. To better grasp the fragmentary character of photography, it would be useful to mention that when the photographers try to build a sequence of the impressions of the urban landscape while traveling by car, they create articulations and connections between the different fragments of reality, that is to say the different photographs. This process of creating a network of fragments of reality pushes the photographers to filter and interpret their photographs, 
to discern the repetitive patterns, and to self-analyse what was the most important for them among all the different views they encountered while travelling by car.

The role of the photographers when they try to assemble a sequence of the different impressions of the travel retrospectively is different from the role of the film-makers who often conceive their films as sequences already produced. In this sense, the role of the photographer is more active, not only retrospectively when they choose which photographs they are going to use and how they are going to assemble them in order produce a meaningful sequence of their trajectory, but also the very moment they decide to push the button and take a snapshot of reality. Their criteria during these phases-the phase of taking the photographs and the phase of assembling them to produce a meaningful network of impressions-are, in the case of the first phase, the extent to which an image stimulates them, and in the case of the second phase, how a specific combination of photographs and their articulation in meaningful assemblages stimulates them and activates the feelings and thoughts that dominated them the very moments they took these photographs. For these reasons, in the case of photography the stimulatory value is more intense than the documentary value. The distinction between causality and intentionality, that the British philosopher Roger Scruton emphasizes in "Photography and Representation" (Scruton 1981), can help us better understand how the stimulatory value of photography functions. What I argue is that the stimulatory value of photography is intensified when the causality and the intentionality are fused to each other in a way that the interpreter of photography is not able any more to distinguish them.

Despite the fact that the paper focuses on the post-war period, with a special emphasis on the 1970s, to situate historically the role of the car in architects' thought and practice it is important to bear in mind leisurebased automobile travel was made popular much earlier, as we look at the founding of Michelin guides in France and the parkway system in the United States (see Leed 1991; Alcolea and Tárrago 2011). The same goes for travel-based photography, which became popular thanks to the $35 \mathrm{~mm}$ camera in the 1930s (see Robertson and Rowland 1989). As John Urry has highlighted, "[i] $\mathrm{n}$ the development of automobility as a distinct culture, north America has been seminally important in providing experiences, scenes and literature which have become icons of the car". The influence of mobility on architecture in the global era has been examined in Travel, Space,

\footnotetext{
${ }^{2}$ John Urry, "Automobility, Car Culture and Weightless Travel: A discussion paper", published by the Department of Sociology, Lancaster University, Lancaster LA1 4YN, UK, at http://www.comp.lancs.ac.uk/sociology/papers/UrryAutomobility.pdf.
}

Architecture, edited by Miodrag Mitrasinovic and Jilly Traganou, in which the latter observes that "the valorization of distance, has [...] characterised contemporary architectural discourse" (Traganou 2016, p. 21; see also Clifford 1997; Alù and Hill 2018), shedding light on how the architecture theory promoted by renowned practising architects emerged as a result of their journeys. Urban historian Christine Boyer, in The City of Collective Memory: Its Historical Imagery and Architectural Entertainments, has also placed particular emphasis on the relationship of the act of travelling, in the case of architects, with the simultaneous perception of "travel narratives, history books, historical painting, and architectural ruins". Boyer interpreted "[t]raveling, visiting museums, studying maps, gazing upon architecture, and even observing a city's plan" as optical means employed by architects in order to organise their "visual memory" (Boyer 1996, p. 228-230).

Pivotal for understanding what is at stake in the case of taking photographs while travelling by car are the exhibitions "The Car and the Camera: The Detroit School of Automotive Photography" (Lewis and Rauhauser 1996) held at the Detroit Institute of Arts in 1996, and "The Open Road: Photography and the American Road Trip" (Campany 2014), held in 2018 at the Milwaukee Art Museum. The latter was based on the interpretation of the photographic road trip as a genre in its own right, tracing photographic road trips from Swiss-American photographer Robert Frank-whose 1955 travels resulted in The Americans (1958) (Frank 1958, 1959; Court 2016; Greenough et al. 2009)-to the present day. The text that Jack Kerouac authored to introduce the latter is one of his most important texts.

Two other exhibition that are important for understanding what is at stake in the case of travel-based photography is "Open city: street photographs since 1950" (Brougher et al. 2001), held at the Museum of Modern Art Oxford in 2001 and at the Hirshorn Museum and Sculpture Garden in Washington, D.C. in 2002, and "Lee Friedlander: America By Car" (Friedlander 2010) held at the Whitney Museum of American Art in 2010 and curated by Elisabeth Sussman and Sondra Gilman, are also valuable for this study. The latter displayed a collection of 192 images taken by Friedlander from his car. Pioneers in the domain of street photography are Robert Frank and Walker Evans (Trachtenberg 1989; see also Papageorge et al. 1981). The former embarked on a photographic project, in 1955, with the objective "to photograph freely throughout the United States, using the miniature camera exclusively" (Alexander 1986, p. 13). This project later became the famous book The Americans and constitutes a visual study of American society. Younger photographers who also specialised in street 
photography are Lee Friedlander-who made the car an actual "form" for making photographs in the 1960s and took part in the exhibition "New Documents" at the Museum of Modern Art (MoMA) in New York City in 1967, curated by John Szarkowski-as well as Garry Winogrand and Diane Arbus. Ed Ruscha's self-published book Every Building on the Sunset Strip (1966) is also an important reference regarding the "snapshot aesthetics" characterising the act of taking photographs from the car. The common ground among these photographers was the elaboration of a "snapshot aesthetics" capturing contemporary urban life in its ordinariness and banality.

Gilles Deleuze, in The Fold: Leibniz and the Baroque (2006), refers to a description of Tony Smith of a roadtrip in an interview he gave in 1966: "a closed car going along an interstate highway that only the headlights are illuminating, and on whose windshield asphalt streams past at top speed. It is a monad, with its privileged zone" (Wagstaff 1966, p. 16). Tony Smith also underscored that "[t]he drive was [for him] a revealing experience [...] [since] it did something for me that art had never done". He related the revealing experience of driving to the effect [of liberating him] [...] from many of the views I had about art", and to the fact that "there had been a reality there which had not had any expression in art" (Storr 1998, pp. 21-21; see also Jasper 2017, pp. 108, 109).

\section{The instrumentality of the architects' gaze: the reciprocal relation between automobile vision and design approaches}

The way the architects take photographs or films from the car is related to the way they conceive architectural design process in the sense that, in many cases, they use these photographs to confirm or reinforce their design arguments. In parallel, their interest in particular typologies that are related to the intensification of the car culture, such as the parking lots or other building typologies that one encounters while traversing the highways and freeways, is apparent in their photographs. Photography from the car, instead of functioning simply as a tool serving to document the visual impressions during the travel, it plays an important role in shaping the architects' own architectural and urban design strategies. Tools coming from the domain of semiotics and semiology ${ }^{3}$ were activated by architects to grasp this new reality and to make sense of it. The phase of taking photographs of these new typologies and signs does not constitute only a phase during which the architects document reality without interpretation. On the contrary, the way they framed

\footnotetext{
${ }^{3}$ For further investigation regarding the relationship of semiotics and semiology with architecture look Jencks and Baird (1969).
}

these new typologies and signs, the specificity of their technique, and the choice of certain typologies and/or signs among other that they encountered during their car travels is closely related to the way they interpreted architecture as a symbolic mode of communication.

The architects' gaze, thanks to the instrumentality of the way the architects look at the landscapes that surrounds them, is related to the desire to re-discover and translate the attributes of the urban landscapes that stimulate their perception into design tools and devices. Architectural culture is characterised by frames of value and thought which drive our logos and praxis. Photography and film are the two means par excellence of capturing the view from the car and have been extensively used by architects during their travels by car. The way the architects conceive the instrumentality of taking photographs from the car is closely connected to the conceptual framework of their architectural thought and practice. Examining three cases of architects that treated the view from the car as a significant means for shaping their design methods, I aim to shed light on the mutual interaction between the view from the car and architectural design strategies. This interexchange between the ways of capturing the views from the car and the formation of new design methods can explain the necessity to establish a new theoretical framework offering the possibility to historians of architecture and urban design to address in a sharp and concrete way the reciprocal relation between automobile vision and design approaches. In order to render explicit how such a new theoretical framework could be useful, I focus on three different cases of architects-John Lautner, Alison and Peter Smithson, and Aldo Rossi-who tried to construct new visual regimes in photography from the car. My main objective while analysing these three cases is to present how new visual regimes in photography from the car informed in various ways the visual attitudes in their designs of buildings.

\section{John Lautner's buildings as apparatuses of accommodating views}

A first example to illustrate the reciprocity between the view from the car and design is the American architect John Lautner, a student of Frank Lloyd Wright, who practiced primarily in California. In the case of Lautner this reciprocity is defined in terms of the visual relation between man and territory. A close analysis of the relationship between Lautner's photographs from the car and his design practice can help us understand the connection between how he used to capture the territory while travelling by car and the design ideas at the centre of his famous residential buildings. Important for understanding the relationship of Lautner's thought with the 
automobile aesthetics is the significant connection of his work with the specific cultural and geographical context of Los Angeles. This connection has been highlighted in Between Earth and Heaven: The Architecture of John Lautner (Olsberg 2008) edited by Nicholas Olsberg.

The main characteristic of Lautner's designs of residential buildings is their strategies of enhancement of panoramic views. The automobile appealed to Lautner and his photo-shots taken during trips are often the quick views or snapshots of a moving viewer. His insistence on capturing the panoramic views from the car is related to the way he designed the residential buildings as apparatuses that aim to capture the panoramic views. For example, before he started designing for a specific site, he used to make collages of the panoramic views on which he noted the possible alternatives of the ways in which the residential buildings that he was invited to design would provide panoramic views. The fact that Lautner used to take his own photographs gives us the opportunity to closely examine his vision regarding not only his own buildings, but also the different landscapes he encountered during his many travels. ${ }^{4}$ Lautner's own travel slides constitute a precious resource, since they represent a visual record equivalent to the more usual sketchbook used by many architects to record their study notes. A close study of his travel slides is useful for understanding how he conceived the relationship between the viewer and the territory, as well as the relationship between the inhabitant and the landscape within which the residential buildings he designed were inscribed.

John Lautner's buildings trigger an ocular-centric vision which cannot but be related to the pre-eminence of landscape views in his conceptual strategies, as it becomes evident not only in his architecture, but also through the views he captured on camera when confronted with various landscapes. His conception of the buildings he designed as optical devices offering panoramic views is evidenced in various annotations throughout his drawings and sketches, such as his comment "CHK view ON SITE!" on one his sketches for the Beyer house, which was completed in 1983. Lautner's photographs from the car reveal his intention to transpose the panoramic views he encountered during his travels by car into the very design of his renowned residential buildings. The panoramic views enhance ocular-centric vision since they push the inhabitants of the houses to extend their vision and to embrace visually as much as possible the landscape. In other words, what was at the centre of

\footnotetext{
${ }^{4}$ In John Lautner fonds at the Getty Research Institute, tens of thousands of slides can be found, illustrating trips throughout the United States, Eastern and Western Europe, Scandinavia, Mexico, Brazil, Japan, Thailand, and Egypt. These photographs of landscapes can inform us on the specific vision that his own buildings introduced and vice-versa.
}

Lautner's understanding of architecture was the connection of the building with its landscape and the conversion of the building into a mechanism of grasping the panoramic view, as in the case of the Chemosphere (the Malin House).

The majority of John Lautner's residential buildings were conceived and function as apparatuses whose primary purpose is to accommodate views. This understanding of his buildings as equivalents of cameras is confirmed by the fact that, on many of his sketches and drawings, he notes the words "eyelids" and "eyelashes". Regarding the primacy of panoramic views for his buildings, Lautner noted: "Usually in the hills you have a panoramic view that people are interested in right away, and so most of my things are curved." ${ }^{5}$ In these words, it becomes evident that Lautner's houses operate as panoramic photographs from the car. His buildings open to a panoramic view of the landscape all at once. As far as the way in which Lautner's spaces seek to embrace views all at once is concerned, the following words are telling: "When standing on a site I search for its particular and unique expression with all my senses. The sweep of my eye and what it embraces merge through years of work and experience with all I have learned and come to know." (Lautner quoted in Rosa et al. 1991, p. 25). Regarding his choice to construct Chemosphere's glass surfaces to tilt inward at the top, Lautner noted: "I wanted it to work like a penthouse overlooking the Valley. I purposely sloped the glass in so when you stand up against it you can't look straight down. You are forced to look at the magnificent view" (Lautner quoted in Rosa et al. 1991, p. 25).

John Lautner said during an interview he gave in December 1990: "It's thinking right from scratch and having a major idea, from inside. I've never designed a façade in my life". According to Dan Kneece, director of photography for the documentary directed by Bette Cohen entitled "The Spirit in Architecture: John Lautner", "[e]verything he did-it was like Panavision!" (Dan Kneece quoted in Yoder (2014, p. 47)). Many houses of John Lautner feature in films. The fact that in the case of more than ten of the films that included shots of Lautner's residential buildings the directors chose to use an expansive aspect ratio of 2.35:1 instead of the more common US widescreen format of $1.85: 1$ is indicative of this capacity of his houses to enhance panoramic views and to embrace the landscape expanding as much as possible the inhabitants' views. Lautner's design strategies were based on a desire for specific dramatic views from his buildings. This desire should be understood and interpreted in

\footnotetext{
${ }^{5}$ John Lautner, interview with Laskey (1986, pp. 15-19).

6 Barbara-Ann Campbell-Lange. John Lautner. Unpublished interview, 10 December 1990.
} 


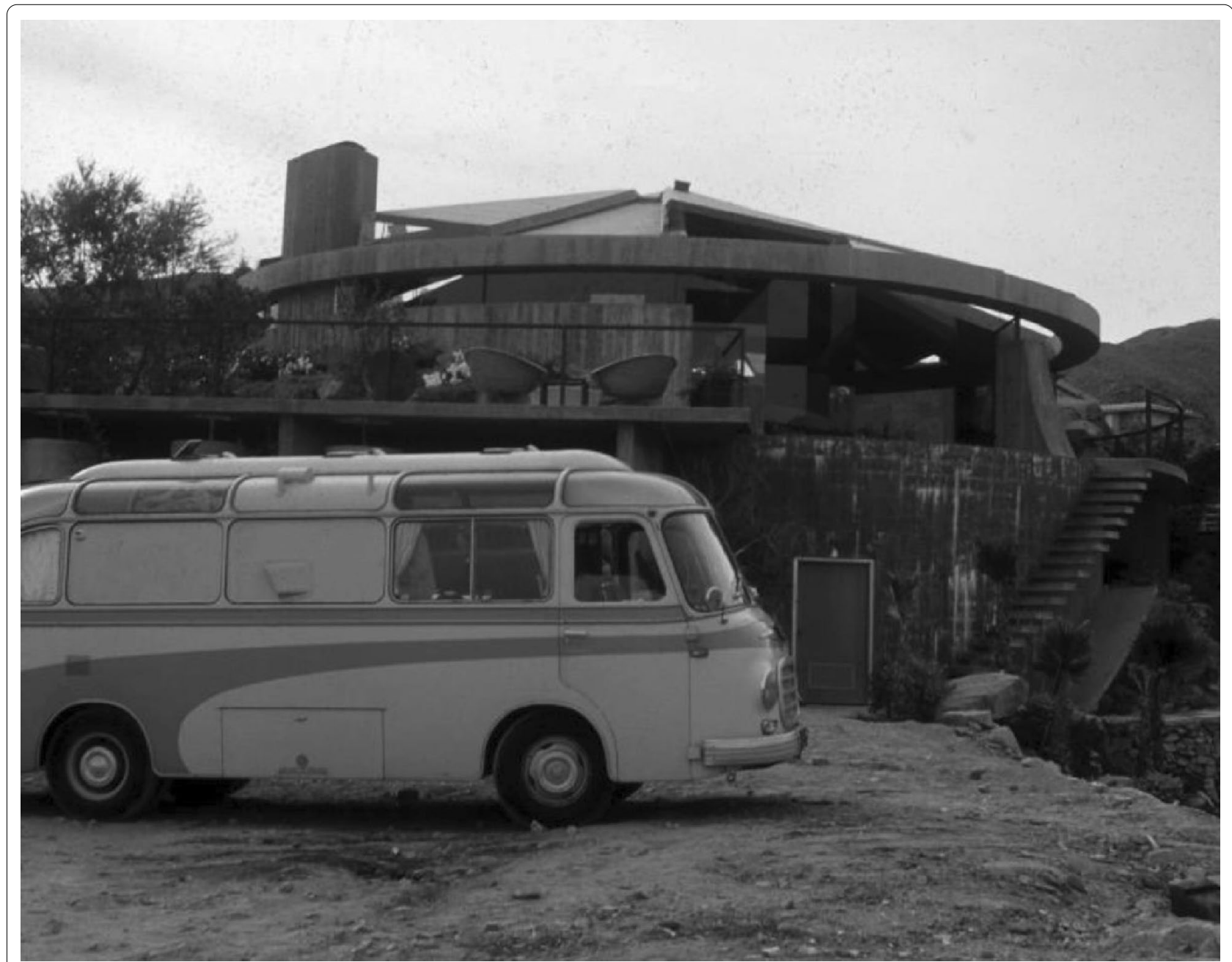

Fig. 1 John Lautner, Elrod house, Palm Springs, 1968. Credits: Photograph by John Lautner. Lautner personal collection

relation to the intention to capture the landscape while travelling by car. Art critic Thomas Keenan has written regarding the Garcia house, which was completed on 1962, on Mulholland drive: "The house stands out on the hill as a hooded aperture, not so much a platform or a container for viewing as the very technology of the gaze. It looks like an eye" (Yoder 2014, p. 49). The fact that this house functions as an eye brings to mind my position that Lautner's buildings function as analogies of cameras intending to embrace the landscape all at once. When Lautner describes the Elrod Residence, he notes that his main design intention was to liberate "the real character of the site" and to avoid "the typical box house". In order to do so, he used the rocks of the site and provided "maximum views, creating total desert livability". Lautner's

\footnotetext{
${ }^{7}$ John Lautner's typescript regarding the description of the design strategies employed in the case of the design of the Elrod Residence. John Lautner fonds, Getty Research Institute, Los Angeles.
}

photograph of Elrod Residence where the residence is depicted next to the automobile invites us to reflect on an analogy between the automobile as an apparatus of encountering new landscapes and the residence as an apparatus of embracing visually the surrounding landscape (Fig. 1).

In a perspective drawing he produced for the Chemosphere, it becomes evident how much emphasis was placed on visually dominating the landscape (Fig. 2). The human figures are represented close to the tilted glass surface, observing the territory. The use of an abstract grid to represent the more distant parts of the viewed landscape on the right of the drawing conveys the desire of the inhabitant's eye to extend their ocular-centric vision to the maximum that their eyes can grasp. Another striking characteristic of this drawing is the Lautner's choice to accentuate the presence of nature and to eliminate the presence of urban elements. His structure is represented as a dominant feature in a 


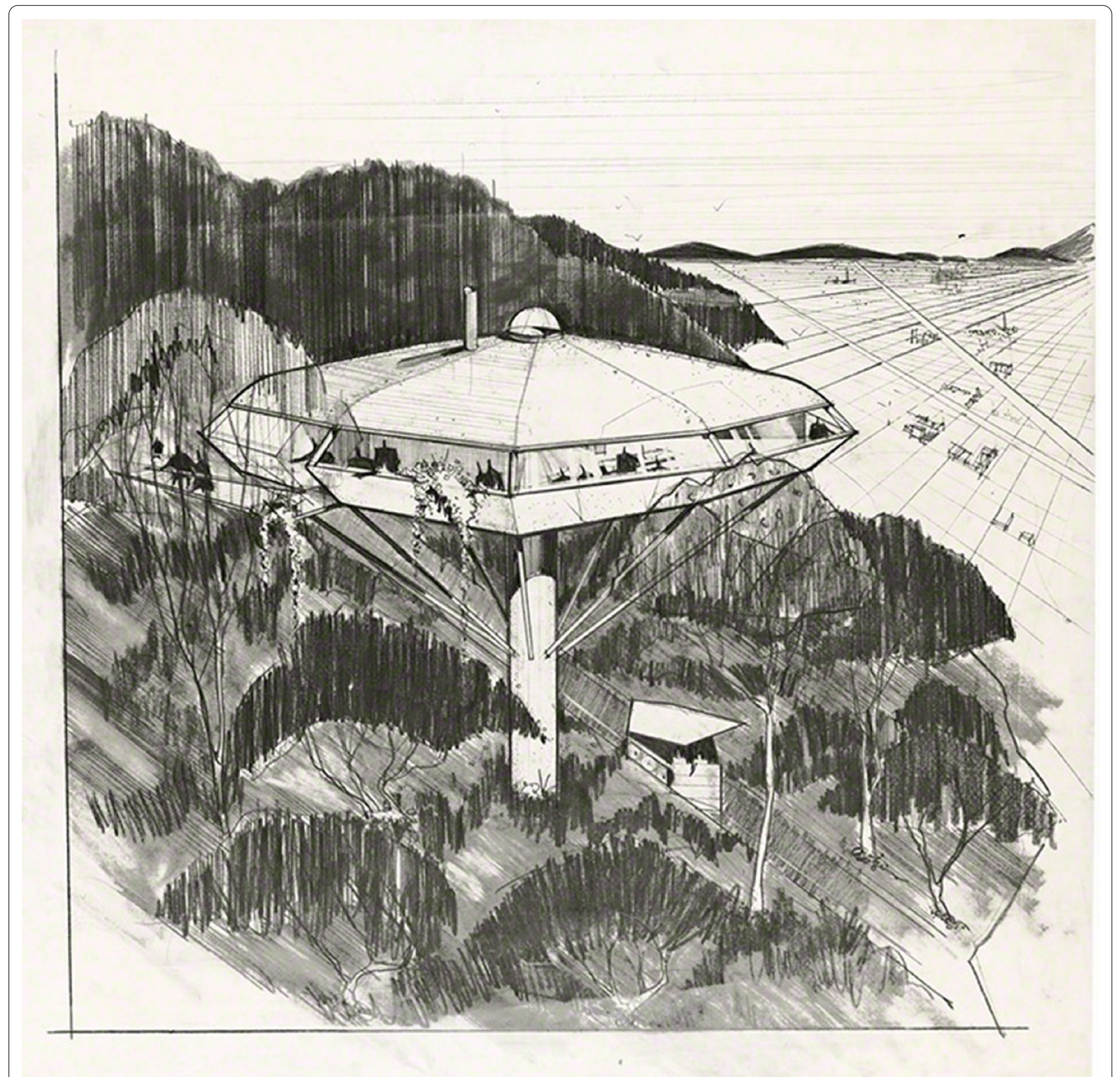

Fig. 2 Malin House (Chemosphere) by John E. Lautner, Hollywood, construction completed 1960. Pencil on vellum drawing, about 1960, $30 \times 30$ $3 / 8$ in. $(76.1 \times 77 \mathrm{~cm})$. Credits: The Getty Research Institute, Gift of the John Lautner Foundation. @ The John Lautner Foundation

natural setting, emphasizing the fact that the building is taller than the trees. Despite the extreme symmetricality of the design, Lautner chose a non-symmetrical organisation of the perspective drawing. This gesture helped him further reinforce the dynamic impression created by the building and the sense of dominating the landscape, extending the view as much as possible. Another characteristic of this drawing worthy of note is its capacity to build an analogy between the way the observer of the drawing grasps the view extending on the right side of the picture and the way the inhabitants visually dominate the landscape.

Lautner remarked regarding Malin Residence, which is also known as the Chemosphere and was completed in 1960: "Looking out at night from just above Mulholland Drive, one gets the feeling of being in a penthouse, hanging in the air suspended 70 stories above Los Angeles. The glass has been purposely sloped inward 
so that when approaching the window one can go only so close to the edge, accentuating the distant panorama". Lautner's persisting intention to conceive the residential buildings he designed as apparatuses aiming to enhance panoramic views is related to his desire to trigger ocular-centric vision. His sketches show that one of his prime concerns was to push the inhabitant of a residential building to extend their vision and to visually embrace the landscape as much as possible. This also explains why he chose to construct the Chemosphere's glass surfaces that tilt inward at the top, in order to force the inhabitants to extend their view of the landscape.

\section{Alison and Peter Smithson's understanding of the car as a cell of perfected technology: car travelling as capture of the sensibility of place}

Alison and Peter Smithson were among the protagonists of the New Brutalism, and were also members of the Independent Group art movement, along with photographer Nigel Henderson and sculptor Eduardo Paolozzi, and the group of architects known as Team 10. Their close relationship with Nigel Henderson, who was like them a member of the Independent Group, should also be taken into account in our endeavour to comprehend how the Smithsons perceived the means of photography in general, and more specifically during journeys by car. Henderson's work, and especially his street photographs taken in London's East End between 1949 and 1953, is pivotal for understanding how photography was instrumental in conceiving representation as the effort to grasp the variable rather than the objective appraisal of reality.

In the case of Alison and Peter Smithson what was really at stake in the way they used to take photographs from the automobile, and in their architectural design processes is their intention to shed light on the cultural aspect of architecture. Before buying their famous Citroëns, they owned a Willys Jeep, and a dark green Volkswagen Beetle. In 1956, in contrast with most CIAM members, who chose to reach Dubrovnik on a ship from Venice, they drove to the tenth CIAM (Congrès Internationaux d'Architecture Moderne) meeting in Dubrovnik in Yugoslavia in the Willys Jeep. Their Citroëns, in chronological order, were a light blue Citroën DS 19 with translucent fibreglass roof, a dark silver Citroën DS 19 with round headlights, a white Citroën DS Safari with tan

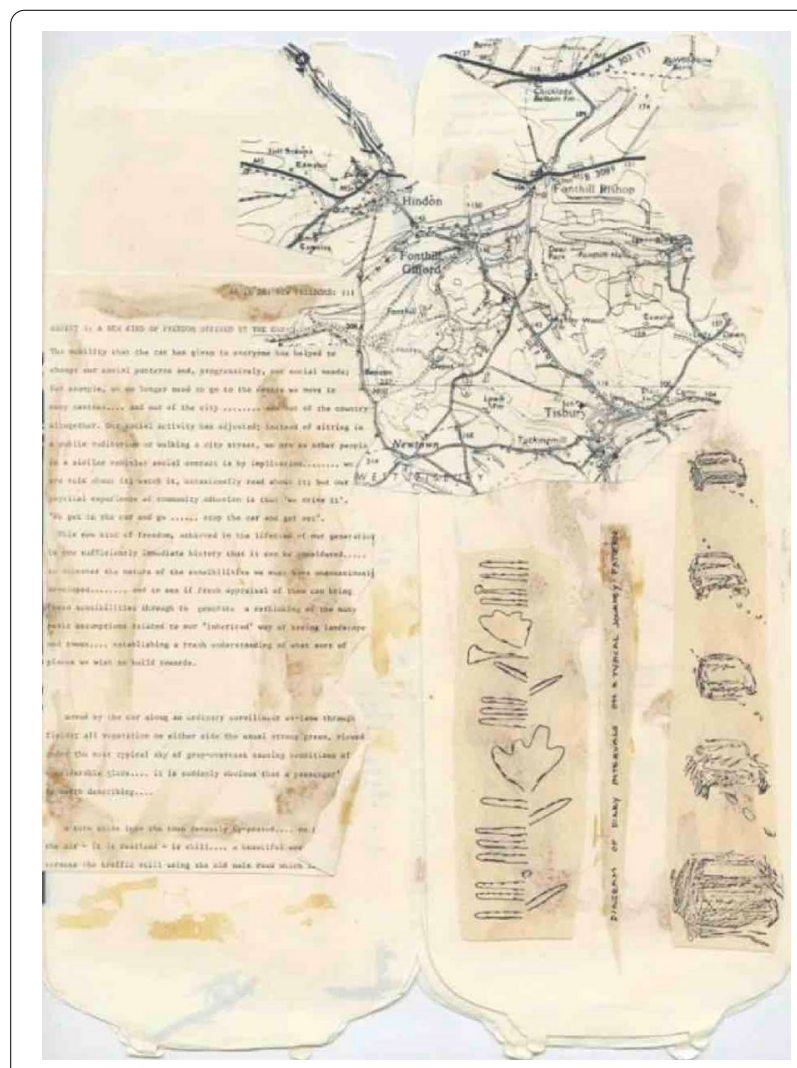

Fig. 3 Mock-up of double page spread AS in DS: an eye on the road. Artwork by Smithson (1982). Credits: Smithson Family Collection

seats and swivelling headlights, a silver Citroën CX, and a dark bronze Citroën XM. ${ }^{9}$ The Smithsons gave much significance to the act of viewing the urban landscape from the car and were convinced that it was of major importance for inventiveness in architecture. Peter Smithson writes, in a manuscript entitled "1956... The DS: The H.O.F. (AND DUBROVNIK!)":

My memory tells me that in 1956 Citroën launched its first post-war car, the Citroën D.S. It was a miraculous wholly new idea of a car. Its body-panels were visually and actually separated... water passed between them and was collected in a gutter-pressing behind; flowing out by air pressure and gravity at low level. It was an aesthetic of explicit joints.

$D S=D E E S S E=G O D D E S S$

$I D=I D E E=I D E A^{10}$

\footnotetext{
${ }^{8}$ John Lautner's typescript regarding the description of the design strategies employed in the case of the design of the Malin Residence or the so-called Chemosphere. John Lautner fonds, Getty Research Institute, Los Angeles.
}

\footnotetext{
${ }^{9}$ Exchange of the author with Soraya Smithson on 17 December 2020.

${ }^{10}$ Peter Smithson, short typed manuscript entitled '1956 ... The DS: The H.O.F. (AND DUBROVNIK!)', dated 28/9/01, H.O.F. file, Alison and Peter Smithson Archive, Frances Loeb Library at Harvard Design School.
} 


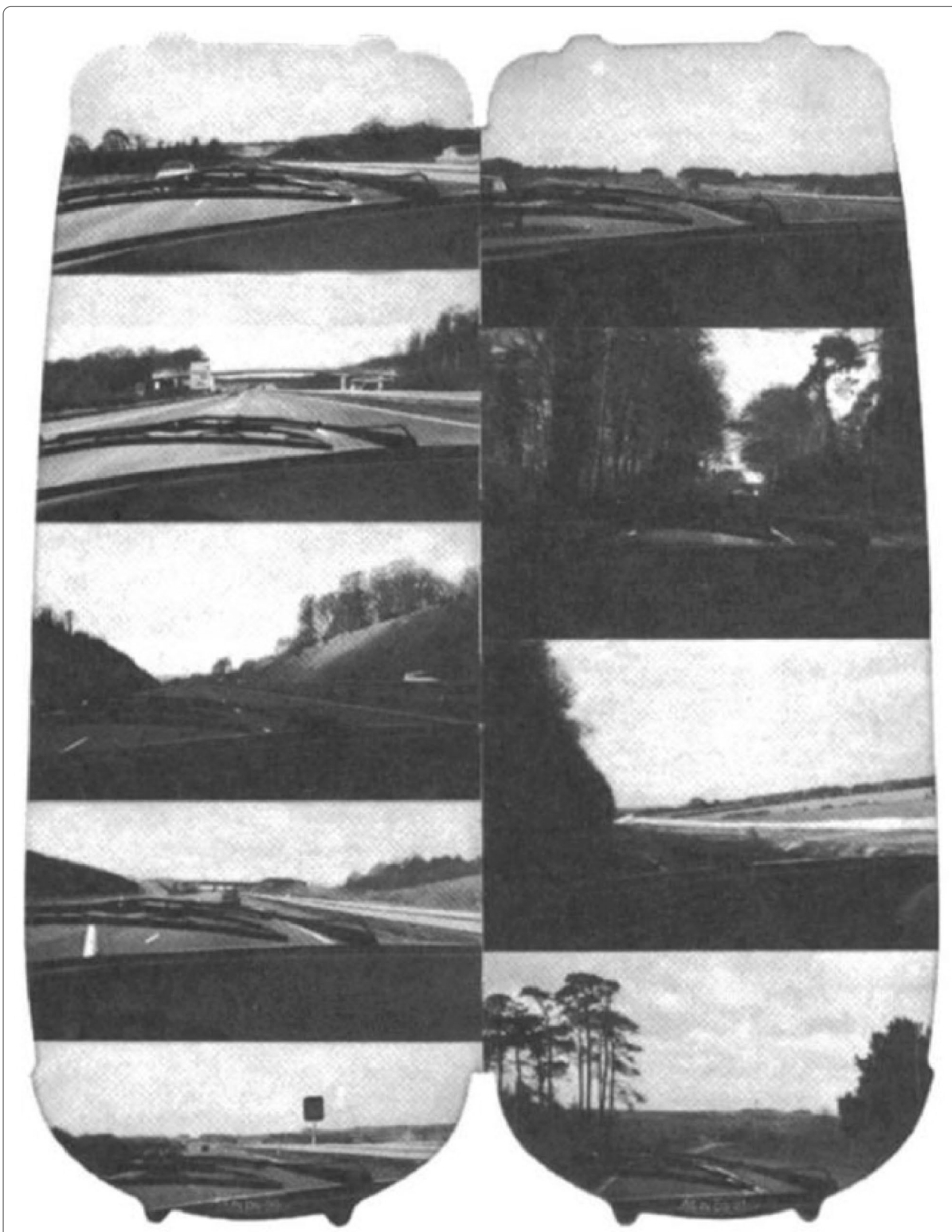

Fig. 4 Pages from Smithson (1983). Credits: Smithson Family Collection 


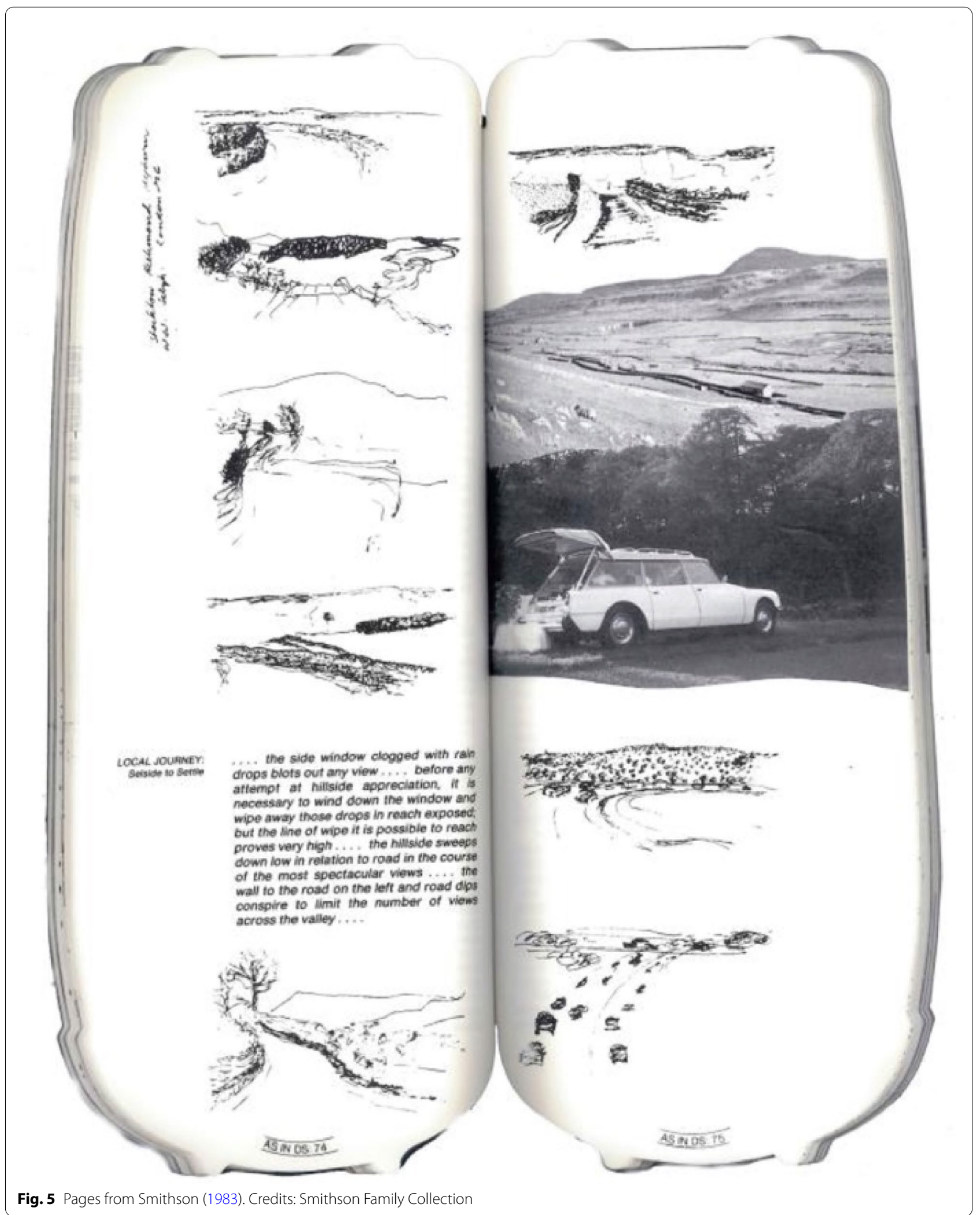




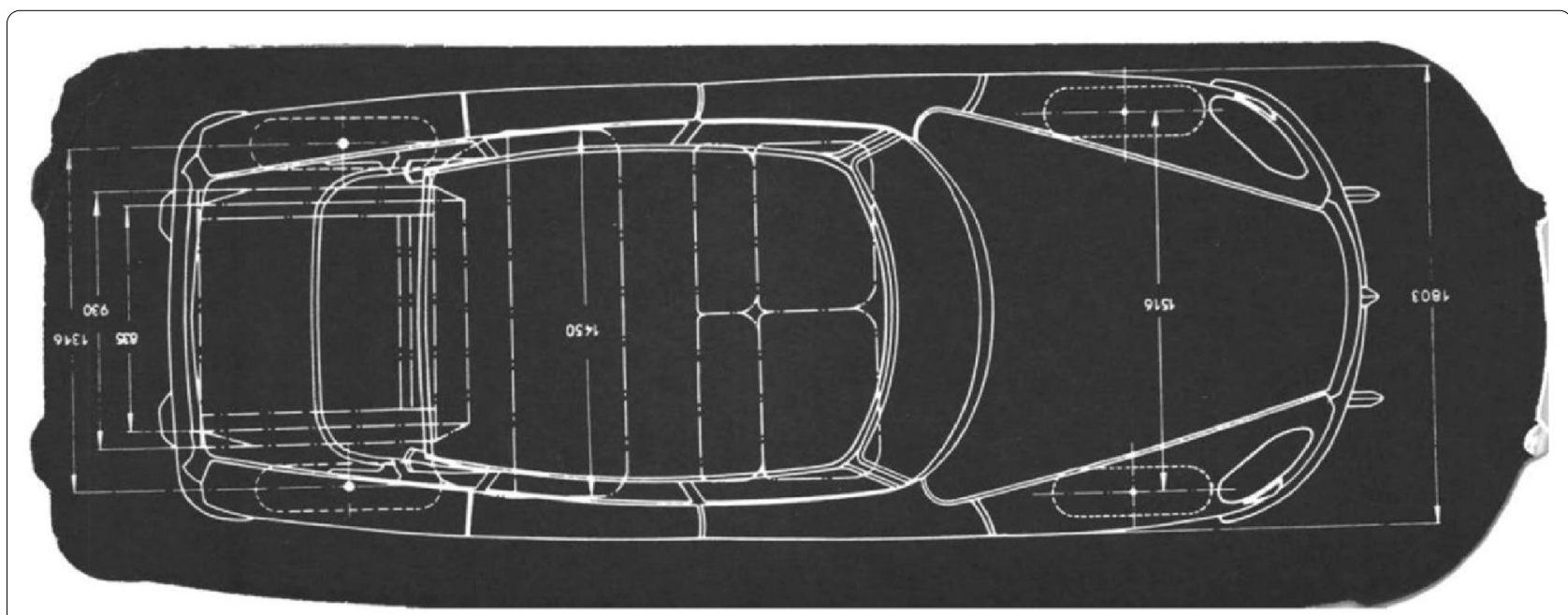

Fig. 6 Interior side of the cover of Smithson (1983). Credits: Smithson Family Collection

This short text by Peter Smithson refers to Roland Barthes's renowned ode to the DS, "The New Citroën", in Mythologies, where he described the DS as the Déesse (the Goddess), equating it with the "great Gothic cathedrals." (Barthes 1972, p. 88) Before their famous journey in a Citroën DS, Alison and Peter Smithson drove a Willys Jeep. In 1956, they drove to the CIAM X meeting in Dubrovnik in Yugoslavia in that Jeep. In contrast with most CIAM members, who chose to reach Dubrovnik on a ship from Venice, the Smithsons preferred the travel by car. Alison Smithson notes, in AS in DS: An Eye on the Road (Figs. 3, 4, 5 and 6), regarding the impact of the car on our sensibilities: "Our sensibilities have been affected by our use of our 'room of wheels' but also, there comes a new awareness of the responsibilities inherent in our comfortable view of just anywhere. Our idea of quality of space, our will to bring though quality in all things, these should also be affected by our possession of a cell of perfected technology" (Smithson 1983, p. 111). The emergence of a new understanding of the citizens' sensibilities due to the generalised used of the car in the post-war society should be interpreted in relation to the welfare state. An important component of the vision of the postwar welfare state was the fact that people started having the capacity to buy their own car and build a whole imaginary around that. This generalized ownership of the car characterizing the post-war welfare state conditions is related to the construction of cultural imaginaries around the automobile.

The Smithsons' effort to address through their written work and their architectural and urban design practice the contrast between the new post-war society and the traditional one, is part of their aspiration to re-invent the role of architecture within a context in which the civic aspect becomes primordial. They conceive the car as an important means within the framework of this endeavour of architecture to respond to the welfare values of the post-war society. The Smithsons' understanding of the car as a "a cell of perfected technology" shows that their interest in travelling by car was not related only to their intention to view the territory in a specific way and to trace itineraries taking advantage of the freedom and spontaneity offered by the car, but also to their admiration of the car as an expression of the perfection of advanced technology.

The photographs that the Smithsons took while travelling by car can help us understand the importance of capturing the identity of places and of daily life for these architects, who were particularly interested in the notion of 'sensibility of place. The possibility to capture various impressions from the car while traveling contributed to their endeavour to grasp what they call 'sensibility of place.' The Smithsons understood architecture as an embodiment of a desired way of life and perceived the directness of photography as a means of representation capable of grasping it. The Smithsons were also using pedestrian street photography in order to explore what they called 'sensibility of place.' They employed two modii of photography: one concerning the pedestrian movement on the street, and one concerning the automobile movement on the street. Their interest in the complementarity between pedestrian and automobile 'sensibility of place' (see Risselada 2017) is worth-mentioning since it demonstrates their concern about the diversity of the ways in which one can experience a place, as a pedestrian and as a driver.

The Smithsons, through their practice, made clear that we should not overlook that this new condition related 
to the social contact by implication that the automobile triggers also the emergence of a new kind of social contact among the co-travellers. For instance, the intimacy that characterised the experience of co-travelling by car is very different from the experience of co-travelling by train. The interior space of a train has many of the characteristics of public space, in contrast with the interior space of a car that is more private. Telling regarding this is Alison Smithson's description of the car, in $A S$ in DS: An Eye on the Road, as "The Private Room on Wheels", which is the title of the fifth chapter of the book. Worthnoting is the fact that Alison Smithson, instead of using the commonly employed word "chapter", uses the word "aspect" in the titles of the chapters of the aforementioned book. In the case of the train the travellers cannot take any initiatives regarding the trajectory and the way they penetrate the urban and non-urban landscapes. On the contrary, in the case of car travelling the freedom to choose one's own trajectory pushes the travellers to feel as subjects open to new discoveries. The interest of the Smithsons in the new social patterns and social needs that emerge thanks to the intensified presence of the car in quotidian life is related to their understanding of the concept of sensibility.

To shed light on how the way the Smithsons used their photographs to build their rhetorical regimes, I could recall that they chose photographs of their quotidian life and the spaces in which they experienced activities that had a symbolic value as far as their appreciation of ordinariness and quotidianity is concerned to render visible and straight forward what was for them the most efficient understanding of architecture. For example, their insistence on including photographs taken during their travels to their weekend house, which is known as Upper Lawn Pavilion or Solar Pavilion, but also photographs of everyday scenes in this house, symbolizes their understanding of architecture as an apparatus of inhabitation. They also included photographs taken from the car in their publications and in the slides that they presented during their lectures as educators at the Architectural Association in London in order to build their rhetorical regimes.

The idea of travelling by car goes hand in hand with the openness to the random encounters. Thanks to the fact that there is a freedom in the ways in which one can transverse and permeate an urban landscape, the drivers are open to the newness of the encounters and to the connections among the different images they encounter. The intuitiveness of the traveller in the case of car travel plays a protagonist role, in contrast with the travel by train. The intuitiveness and freedom characterising the way in which the driver chooses their own trajectory makes the travellers that are in the car to be in state of greater openness and curiosity in comparison with the case of train where the trajectories are repetitive and preestablished. The way architects photograph landscapes that they encounter while traveling by car is related to an unmediated point of view, which brings to mind the notion of 'objet trouvé' ('found object') that André Breton used in order to refer to the 'surrealist delight' (Bate 2003, p. 245) related to the conflict between the object wished for and the object found.

The notion of 'as found', which was at the heart of Alison and Peter Smithson's thought, could be compared to the notion of 'objet trouve' elaborated by Breton given that both concepts derive from the intention to embrace the non-predictable encounters and to observe the very materiality of the artefacts one encounters. As Claude Lichtenstein and Thomas Schregenberger remark, Alison and Peter Smithson [...] began to write about [the notion of the 'as found' [...] in 1990" (Lichtenstein and Schregenberger 2001, p. 8). However, in their text entitled "The 'As Found' and the 'Found", Alison and Peter Smithson mention:

In architecture, the "as found" aesthetic was something we thought we named in the early 1950s when we first knew Nigel Henderson and saw in his photographs a perceptive recognition of the actuality of his house in Bethnal Green: children's pavement play-graphics; repetitions of "kind" in doors used as site hoardings; the items in the detribus on bombed sites, such as the old boot, heaps of nails, fragments of sack or mesh and so on. ${ }^{11}$

This "perceptive recognition of the actuality" is very telling for understanding how the Smithsons related their interest in the 'as found' to their act of taking photographs. Another formulation employed by the Smithsons in the same text to describe the specific vision implied by the 'as found' aesthetics is "the watchful eye" (Smithson 2001, p. 40).

Two exhibitions that are important for grasping how the Smithsons understood the notion of the 'as found' is "Parallel of Life and Art", which was held at the Institute of Contemporary Arts (ICA) from September to October in 1953 and organized by the architects Alison and Peter Smithson, the photographer Nigel Henderson and sculptor Eduardo Paolozzi, all members of The Independent Group, and "This is Tomorrow", which was held at London's Whitechapel Gallery from 9 August to 9 September 1956. Pivotal for interpreting these exhibitions are Reyner Banham's seminal text "The New Brutalism", and Alison Smithson's homonymous text, both

\footnotetext{
${ }^{11}$ Alison and Peter Smithson, "The 'As Found' and the 'Found", in Lichtenstein and Schregenberger (2001, p. 40).
} 
published in 1955. Alison Smithson saw "New Brutalism" as a gesture against academicism. The redefinition of the way of life was at the centre of "New Brutalism". Despite the divergences between the Smithsons' and Banham's interpretation of the transformation of the way of life, the reinvention of the experience of inhabitation and the ethical implications of the way of life was central for both. Reyner Banham also employed the expression 'memorability as an image' to describe the anti-aesthetics of "New Brutalism". The concepts of 'memorability as an image' and the 'as found' cannot but be understood in conjunction with the ideals of the post-war British welfare state and the new formation of citizenship that accompanied the program of the Architects' Department of London County Council (LCC) and London's highly prolific rebuilding campaign following WW II.

Another parameter that should also be taken into consideration when we reflect upon the aforementioned exhibition and especially "This is Tomorrow" is the fact that that same year the Smithsons designed the "House of the Future", a prototype for an ideal house for a foreseeable future which. As Todd Gannon reminds us, in Reyner Banham and the Paradoxes of High Tech, this project was based on a study they made on "American automobile design" (Gannon 2017, p. 37; see also Colomina 2004). Reyner Banham also highlighted the "aesthetic of panels and joints" (Banham 1955, p. 361; Gannon 2017, p. 37) characterizing the "House of the Future".

Lichtenstein and Schregenberger remarked that "[a] $\mathrm{s}$ found is the tendency to engage with what is there, to recognize the existing, to follow its traces with interest" (Lichtenstein and Schregenberger 2001, p. 8), and juxtapose the engaged way of observing related to the notion of the as found to the "disinterested pleasure' of the Enlightenment". They also mentioned that the approach of the 'as found' is "a realistic [, an ethical, and an antiutopian] approach to the world", relating its antiutopian character to the interest in concepts such as "directness, immediacy, rawness, and material presence", and to its "concern with the here and now". An aspect of the concept of the 'as found' that should be taken into consideration is the fact that, as Lichtenstein and Schregenberger argue, the "as found" attitude is antiutopian (Lichtenstein and Schregenberger 2001, p. 9).

We could make the hypothesis that the act of taking photographs was perceived by the Smithsons as a means of interpreting "how the existing built fabric of the place had come to be as it was" (Smithson and Smithson 2001, p. 40; Massey 1995; Robbins 1990).$^{12}$ In "The

\footnotetext{
12 Alison and Peter Smithson, “The 'As Found' and the 'Found", in Robbins (1990, p. 201). See also Massey (1995).
}

'As Found' and the 'Found"', the Smithsons highlight that they "were concerned with the seeing of materials for what they were: the woodness of wood; the sandiness of sand" (Robbins 1990, p. 201; see also Massey 1995). The Smithsons were interested in the face value confrontation with things, and in the real living contact with the things themselves (Scalbert 2018; Celant 2018). ${ }^{13}$ They conceived the 'as found' as "a new seeing of the ordinary, an openness to how prosaic 'things' could re-energise our inventive activity" (Smithson and Smithson 2001, p. 40). ${ }^{14}$ Viktor Sklovskij's following remark concerning his concept of estrangement (ostranenie) could help us interpret this new seeing of the ordinary that characterises the Smithsons' vision (Rossbacher 1977; see also Tihanov 2005): "In order to recover the feel of life, to feel things, to make the stone stony, there exists that which is called art. The goal of art is to give feelings to a thing as something seen, not as something recognized. The device of art is the device of "estrangement' of things" (Sklovskij 1925, p. 12).

Despite the fact that the Smithsons, through their conception of "memorability as an image" (Banham 1955, p. 357), seemed to prioritize the documentary over the stimulatory value, my research aims to put this into question. The concepts of the 'as found' and the 'memorability as image' are useful for interpreting the Smithsons' photographs (Figs. 7, 8), since they are closely related to the semi-directed gaze of the architects while taking photographs from the car. To understand both notions-the 'as found' and the 'memorability as image'-one should recall the very philosophy of the so-called New Brutalism. To do so, one should examine closely not only Smithsons' conception of the "New Brutalism" in their short essay in Architectural Design in 1955 (Smithson and Smithson 1955), but also Reyner Banham's well-known article "The New Brutalism", in which he pays special attention to the exhibition "Parallel of Life and Art", held at the Institute for Contemporary Art (ICA) in London in 1953 and curated by Alison and Peter Smithson, Nigel Henderson and Eduardo Paolozzi. The Smithsons instrumentalised the concept of "New Brutalism" in order to redefine function. In 1955, 3 years after the competition for the Golden Lane project, Alison Smithson defined "New Brutalism" as follows:

\footnotetext{
${ }^{13}$ See Scalbert (2018). Regarding the directedness of the material in arts see also Celant (1969)

14 Alison and Peter Smithson, “The 'As Found' and the 'Found", in Lichtenstein and Schregenberger (2001).
} 


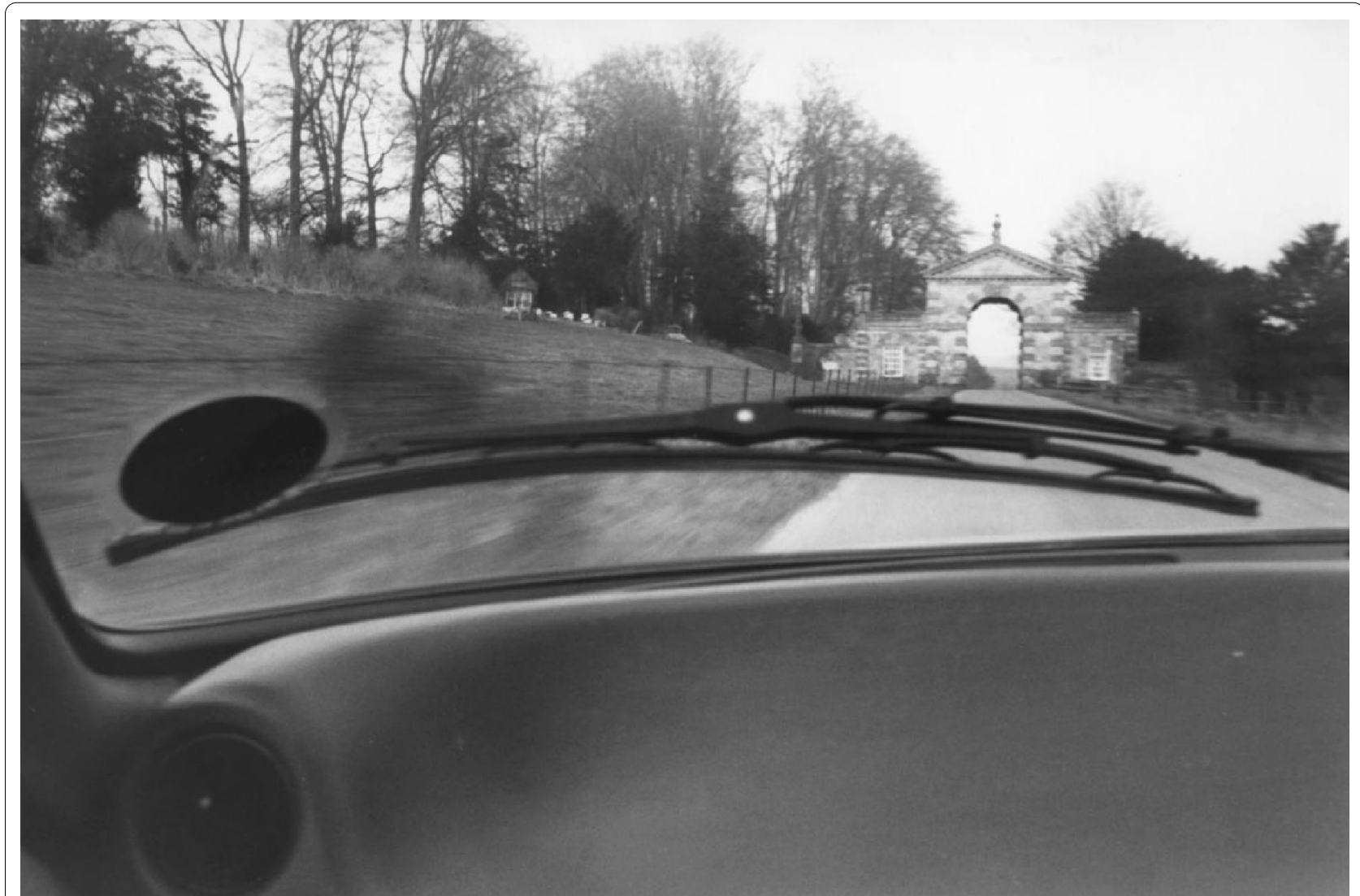

Fig. 7 Photograph taken from Citroën CX departing from Upper Lawn and approaching the outer gate of Splenders, Beckford's father's house. Photograph by Alison Smithson, March 1982. Credits: Smithson Family Collection

The New Brutalism is the extension of the original functionalism (Constructivism and the Esprit Nouveau) in that it is the poetry of the natural order $-a$ seizing on the essence of the programme, an attitude which is fundamentally anti-academic even in a period when anti-academic has become academic. ${ }^{15}$

Reyner Banham, in "The New Brutalism”, described New Brutalist aesthetics "as being anti-art, or at any rate anti-beauty in the classical aesthetic sense of the word" and employed the concept of 'memorability as an image' (Banham 1955). Helpful for better grasping what is at stake in the case of the Smithsons' act of taking photographs from the car while travelling is Banham's remark that "an image is what affects the emotions" (Banham 1955; see also Smithson and Smithson 1955).

${ }^{15}$ Alison Smithson, "New Brutalism", first page of the two-page unpublished typescript dated 7 March 1955. The Alison and Peter Smithson Archive, Special Collections, Frances Loeb Library, Graduate School of Design, Harvard University.
A text that is also useful for understanding how Alison and Peter Smithson used photography is Andrew Higgott's "Memorability as Image: The New Brutalism and Photography", where the latter, referring to the photographs of the Smithsons' Hunstanton School by Nigel Henderson, underlines that Henderson's photographs "represent [...] a building that is the product of a process, that expresses the specific incident, resonating with life and reifying the particular rather than the ideal" (Higgott 2012, p. 285). ${ }^{16}$ To comprehend the relationship between the aesthetics implied by the Smithsons' tendency to take photographs from the car and Henderson's approach to photography, we can think that Henderson's work, and especially his street photographs taken in London's East End between 1949 and 1953 (Coward 2017), is pivotal for understanding how photography was instrumental in

\footnotetext{
${ }^{16}$ Andrew Higgott, "Memorability as Image: The New Brutalism and Photography", in Higgott and Wray (2012, p. 285).
} 


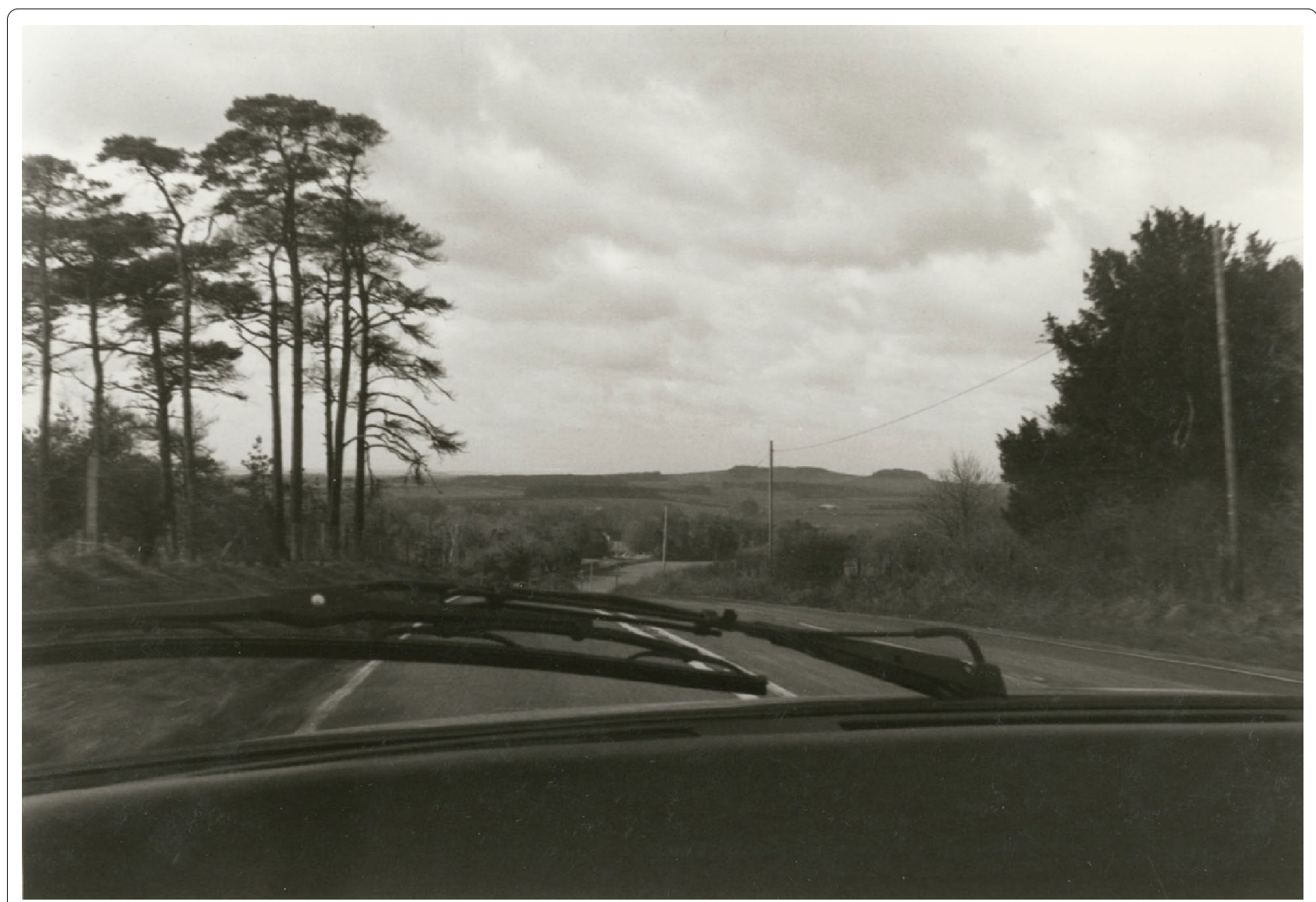

Fig. 8 Photograph taken from Citroën CX, Spring, 1982. Photograph by Alison Smithson. Credits: Smithson Family Collection

conceiving representation as the effort to grasp the variable rather than the objective appraisal of reality. Ordinariness acquires a new status and becomes a source of invention for the Smithsons, who were attracted to the 'as found. Photography was for the Smithsons a means able to capture the ordinary and the 'as found'.

A notion that is very central for the Smithsons and for their understanding of the impact of the automobile on the emergence of a new perceptual regime is that of sensibility. Reading AS in DS: An Eye on the Road, one realises how often this notion appears and how important it is for them. AS in DS: An Eye on the Road was described as "A Sensibility Primer", and as "a diary of car-movement recording the evolving sensibility of a passenger in a car to the post-industrial landscape". ${ }^{17}$ The status of this book is close to that of the travel diary, as is evidenced in the words that appear on its back cover: "In this diary-a passenger's eye on English roads in the 1970's-a sensibility to car movement has its beginnings".

${ }^{17}$ Peter Smithson in Smithson (2001, p. 1).

\section{Aldo Rossi's understanding of the act of taking photographs from the car: Polaroid as transformation of urban artefacts into objects of affection}

In the case of Aldo Rossi, the act of taking photographs while travelling by car is related to his conception of collective memory. For Rossi, the city was the locus of the collective memory. In order to better understand Rossi's conception of memory and especially the distinction between individual and collective memory, it would be useful to take into account Maurice Halbwachs' understanding of the notion of collective memory in $\mathrm{On} \mathrm{Col-}$ lective Memory (Halbwachs 1950, 1992), which played a significant role for the theory that Rossi developed in The Architecture of the City (Rossi 1966, 1982). One of the subtitles of the chapters of Rossi's book is "The Thesis of Maurice Halbwachs". Rossi draws upon Halbwachs' theory to explain how the personality of an individual or a group contributes to urban changes and vice versa. In The Architecture of the City, he cites the following passage from Halbwachs' On Collective Memory: 
When a group is introduced into a part of space, it transforms it to its image, but at the same time, it yields and adapts itself to certain material things which resist it. It encloses itself in the framework that it has constructed. The image of the exterior environment and the stable relationships that it maintains with it pass into the realm of idea that it has of itself (Halbwachs quoted in Rossi 1982, p. 130).

Aldo Rossi related his attachment to the objects to the fact that capturing them though polaroid photography they become objects of affection. In Rossi's thought, viewing urban artefacts as objects of affection was part of the process of transforming them into constitutive components of collective memory. Rossi related the act of transforming architectural and urban artefacts into objects of affection to the act of encountering them while travelling by car, on the one hand, and to the act of photographing them, on the other hand. For this reason, he underscored, in many instances, that the act of observing new landscapes and typologies while travelling forces us to invent new design methods. Rossi, during his stays in the United States, was not only interested in the typology of the skyscraper. He was particularly interested in other typologies the he encountered in the American cities. During his travels by car in the United States in the late seventies and the early eighties - the periods of his first visiting professorships in various universities there, such as the Cooper Union, and Cornell University among other universitieshe was particularly attracted to typologies he encountered for the first time, such as huge complexes of one-family houses in California and mobile homes in Texas. This becomes evident from what he said to Diana Agrest during an interview he gave to her for Skyline in 1979:

I have seen huge complexes of one-family houses in California and mobile-homes in Texas, as well as the new buildings in New York City, and, personally, I don't have any moralistic feelings toward these works; I even found them stimulating (Rossi in Rossi $1979 a, p .4)$.

Rossi's preference for Polaroid photographs is related to the fact that he had connected the act of taking photographs to the immediacy of the production of the photography that can only be achieved in the case of Polaroid. Paolo Costantini remarks regarding Rossi's use of Polaroid, in "Things Which Are Only Themselves": "The Polaroid image is silent and enigmatic, immersed in the language of existence-a private fragment that blends with the life of the author, becoming an object of affection" (Costantini 1996, p. 13).$^{18}$ Constantini

\footnotetext{
${ }^{18}$ Paolo Constantini, “Things Which Are Only Themselves", in idem., Costantini (1996, p. 13)
}

also highlighted that "every fragment of the places seen by Rossi seems to send us on to the next, as in a richly comparative atlas" (Costantini 1996, p. 14). This comment of Constantini is indicative of the way in which one should interpret Rossi's photographs as components of a complex apparatus or dispositif. Constantini, to render explicit how one should relate Rossi's photographs among them while interpreting them, refer to an enlightening remark of Ghirri:

Lined up, one after the other, these places form a kind of strange sequence made of stones, churches, gestures, light, fog, branches coated with heat-frost, blue seas and they become our impossible landscape, with no scale, without a geographic order to help us orient ourselves, a tangle of monuments, lights, thoughts, objects, moments, and metaphors forming the landscape we are searching for in our minds (Luigi Ghirri quoted in Costantini 1996, p. 14).

These reflections of Constantini and Ghirri about Rossi's Polaroids can help us realise what Rossi meant when he remarked, in "The Meaning of Analogy in my Last Projects", that "the most exciting experience [he] [..] had visiting [American] cities [...] is that they are loaded with living history" (Rossi 1979a). Rossi argued that his encounter with new cities made him realise how important it is "reflect in architecture the vitality of experience" (Rossi 1979b). The vitality of experience to which Rossi referred is related to the impact that the typologies he encountered during his car travels had on his design strategies. Rossi remarked regarding the influence that his travels in the United States had on his design approach: "I will say only that in this country, analogies, allusions, or call them observations, have produced in me a great creative desire and also, once again, a strong interest in architecture" (Rossi 1979b). His fascination with the "living history" of American cities reveals that he conceived architecture's individual and collective dimension as always intermixed and superimposed in a never-ending game. Rossi insisted that "[a] knowledge of the city [...] enables us not only to understand architecture better, but also, above all as architects to design it". ${ }^{19}$ Rossi believed that visiting new cities helped him invent new methods of architectural design methods or enrich one's existing architectural design methods.

\footnotetext{
${ }^{19}$ Laine and Rossi (1979). This text was based on an address that Rossi deliv ered at the Graham Foundation for Advanced Studies in the Fine Arts in Chicago on March 1, 1979.
} 
The act of taking photographs while travelling by car functioned, for Rossi, as an instrument serving to convert architectural and urban artefacts into objects of affection. His understanding of the notion of typology and the way it changed throughout his career in relation to his experience, and especially to his travels, could be understood as an endeavour to respond to the need of understanding what are the components of the cities that allow us to conceive them as objects of affection. Throughout his life, Rossi gave several definitions of the term typology. One of them is the following: "in fact by concept of typology I mean the concept of a form in which human living expresses itself in a concrete way." (Laine and Rossi 1979). His photographs of the various typologies he encountered while driving from one American city to another could be interpreted as gestures aiming at grasping how "human living expresses itself in a concrete way" (Laine and Rossi 1979). Peter Eisenman underscores, in the preface of the American translation of Larchitettura della città, that in the case of Rossi, "[t]ype is no longer a neutral structure found in history but rather an analytical and experimental structure which now can be used to operate in the skeleton of history; it becomes an apparatus, an instrument for analysis and measure" (Eisenman 1982, p. 7)..$^{20}$

As we can read in in Rossi's preparatory notes for his seminars at the Politecnico di Milano for the academic year 1966-1967, he related the notion of type to the search of solutions that can take into consideration the relations between the distributive, stylistic, economic and constructive characteristics of architectural and urban form. ${ }^{21}$

The understanding of the act of taking photographs while travelling by car as a means of converting architectural and urban artefacts into objects of affection is related to the thoughts that arose in Rossi's mind when he had the opportunity to encounter new typologies of buildings during his travels by car. In order to shed light on the relationship between Aldo Rossi's act of taking Polaroid photographs during his travels by car and his understanding of architectural design practice, I could refer to his following remark: "the Polaroid impressed me immediately as a very different sort of instrument: photograph of time ever fleeting, the love of a moment, the pursuit of life, etc. ..." (Aldo Rossi 1996, p. 73). Peter Buse notes, in The Camera Does the Rest: How Polaroid Changed, that "[t]he Polaroid process came to be

\footnotetext{
${ }^{20}$ Peter Eisenman, “The Houses of Memory: The Texts of Analogue," in Rossi (1982, p. 7).

21 Aldo Rossi's preparatory notes for his seminars at the Politecnico di Milano for the academic year 1966-1967, Aldo Rossi papers, Getty Research Institute, Los Angeles, California.
}

known as 'instant photography"' (Buse 2016, p. 9). Buse also sheds light on "the Polaroid's capacity to produce a series of images immediately and in the very space being photographed" (Buse 2016, p. 16). He also sheds light on the tension between "the Polaroid as popular snapshot and the Polaroid as aesthetic object" (Buse 2016, p. 16), distinguishing three main applications of Polaroid photography: the artistic, the popular, and the practical and highlighting the interest of the company in the potential overlap between these three applications. A question that arises is whether Rossi conceive Polaroid as a popular snapshot or as an aesthetic object. What I argue here is that his awareness of this potential overlap that led him favour Polaroid photography against other types of photography. To better grasp the specificity of Polaroid, we could explore further in which sense it differs "from other forms of snapshooting, beginning with the products of its great competitor, Kodak" (Buse 2016, p. 20). The fact the in the case of Polaroid photography the photographer can have in their hands the picture very shortly after the moment of taking the photograph makes memory less important than in the case of other photographic technologies, such as the Kodak and the other forms of photography that existed before the appearance of digital photography. Rossi's preference for Polaroid over other kinds of photography offers us the possibility to understand how he related the immediacy characterising Polaroid photography with the act of transforming architectural and urban artefacts into 'objects of affection' through the act of taking photographs while travelling.

Pivotal for understanding the specificity of Rossi's gaze when he took photographs during his travels by car is his conception of the notion of 'urban fact' (fatto urbano), and the impact that this notion had on his experience of the architectural and urban artefacts as objects of affection. Rossi defines as urban facts the architectural and urban artefacts that constitute the city, giving meaning to the life of the city. The way urban artefacts are related to memory is very important for understanding what was at stake at the very moments that Rossi decided to take photographs of the components of a city that he considered as urban facts.

Aldo Rossi started taking Polaroid photographs during his journeys of the late 1970 s, nearly a decade after starting noting his first impressions in his quaderni azzuri. Aldo Rossi's 47 quaderni azzuri (1968-1986), strongly reminiscent of travel diaries, both in form and content. On the cover of many of them, included his notes during his travels. (Dal Co 2000). ${ }^{22}$ His Polaroid photographs,

\footnotetext{
22 Aldo Rossi's 47 quaderni azzuri (1968-1986), strongly reminiscent of travel diaries, both in form and content. On the cover of many of them, included his notes during his travels; see Dal Co (2000).
} 


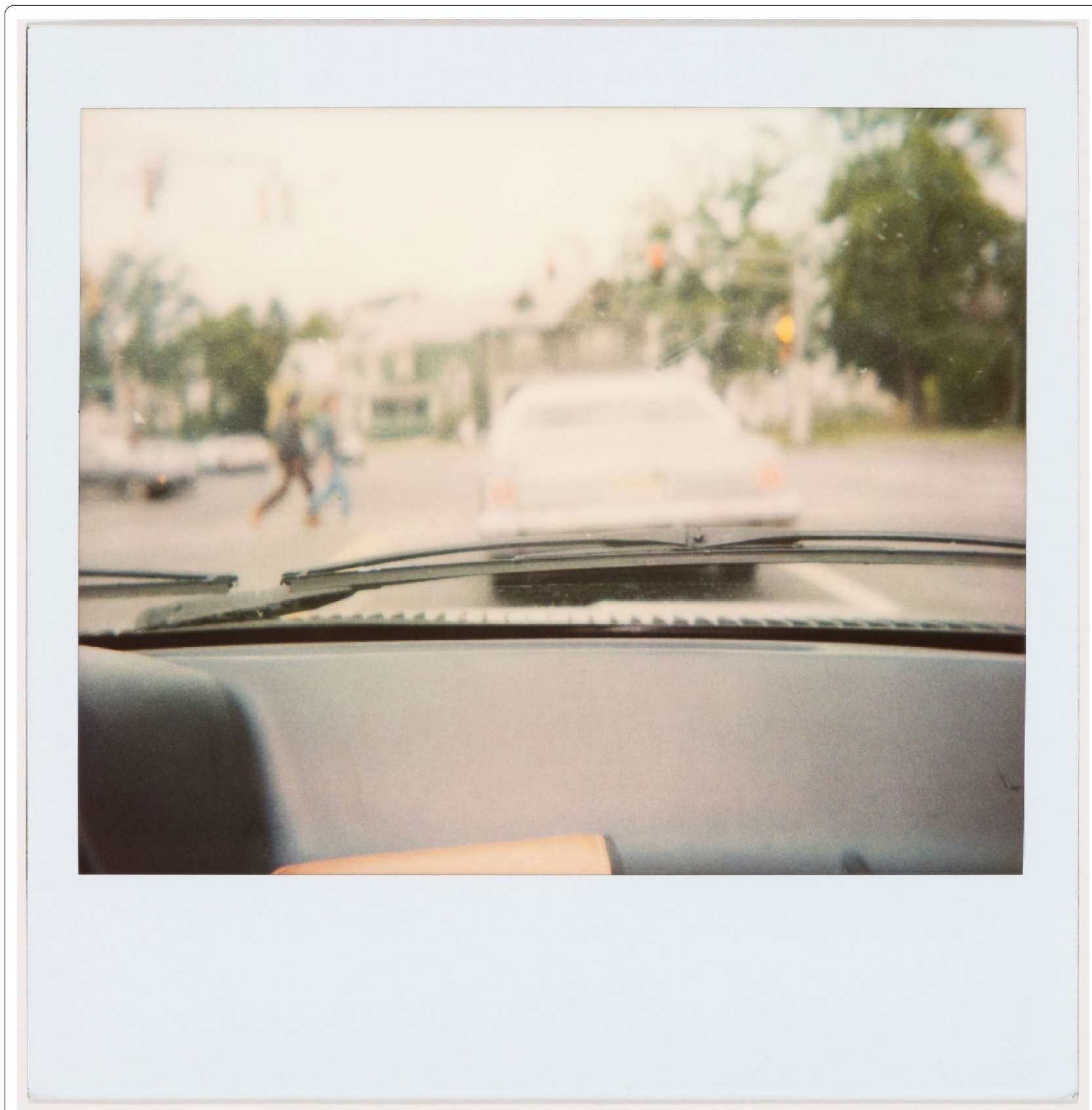

Fig. 9 View of a street from a car windshield, United States, 1980s-1990s. Polaroid Photograph by Aldo Rossi. Credits: Aldo Rossi fonds, Canadian Centre for Architecture (CCA), Fondazione Aldo Rossi

which documented journeys and his whereabouts, include images of boats crossing a river in Bangkok, a Shaker village in Massachusetts, and the Leaning Tower of Pisa, and constitute a visual diary of the Italian architect and an important source for understanding his use of travel-photography in order to organise his visual memory. The photographs he took Aldo Rossi through a car windshield in the United States during the 1980s and 1990s (Fig. 9), are informative regarding the way his travel in various areas of the United States influenced his understanding of the city. Among the photographs he took during this period, one can find several photos depicting facades of stores he encountered while travelling by car, such as a Lebanon Supermarket in Massachusetts (Fig. 10). These photographs by Rossi do not only come from his journeys in the United States, but also 


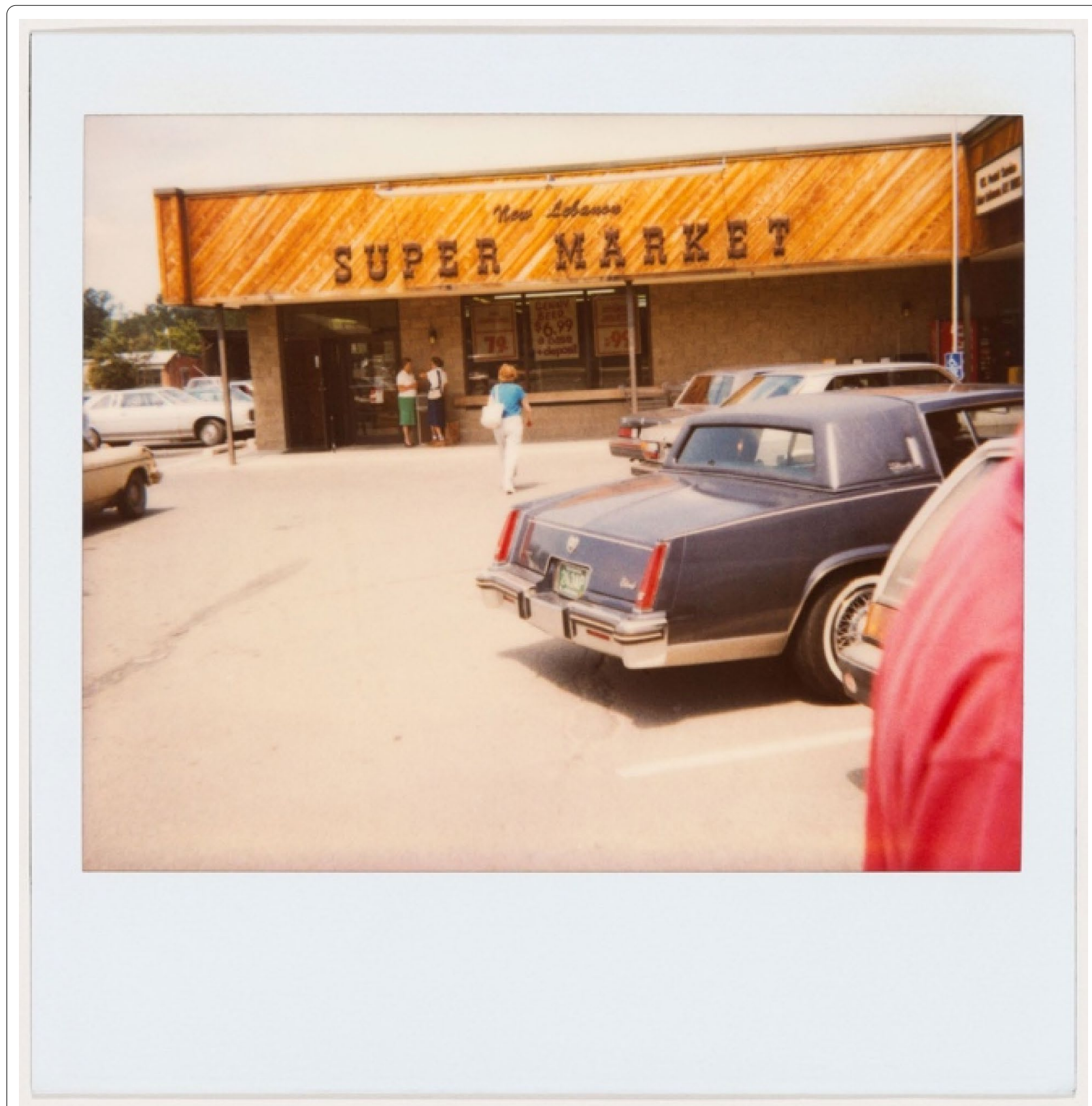

Fig. 10 Facade of the New Lebanon Supermarket, Massachusetts, United States, 1980s-1990s. Polaroid Photograph by Aldo Rossi. Credits: Aldo Rossi fonds, Canadian Centre for Architecture (CCA), Fondazione Aldo Rossi

from his travels by car in France, Greece, and Italy, where Rossi took several photographs of facades of stores and advertisements he encountered while driving. Among them I could refer to a photograph of a fake palm tree and Ristorante Pizzeria sign along the road taken somewhere in Italy during the 1980s-1990s, a photo of a parking lot with a young boy in Dole in France in July 1980, as well as to a photo of the facade of a butcher's shop somewhere in France in the 1980s-1990s. Observing Rossi's Polaroid photographs taken from the car, a question that emerges concerns the extent to which Rossi's perception of advertisements, facades of stores and signs from the car differs from the 'pop agony' defined by Robert Venturi, Denise Scott Brown and Steven Izenour in Learning from Las Vegas (Venturi et al. 1972), which, according to Andrew Leach, "took the stance that the interaction 
between architecture and the city, building and street, had been irrevocably altered by the advent of motorized transport" (Leach 2015, p. 6). Martino Stierli, in order to interpret the new recognition of commercial and popular signs during the 1960s and 1970s, employs W.J.T. Mitchell's definition and analysis of the "iconic turn" (Mitchell 1986).

\section{Shaping a new theoretical frame to approach the role of the view from the car}

The article illuminated the reasons for which the view from the car is important for understanding the specificity of the gaze of the architects and its significance for the establishment of new architectural and urban design methods. My objective was to make clear that there is the need for more research on this topic, on the one hand, and a necessity to shape interpretative tools that would make possible to diversify the ways of viewing the landscape and urban contexts while travelling by car, on the other hand. An aspect regarding the special status of the gaze at stake when the architects take photographs from the car while travelling is its semidirectedness. This semi-directedness refers to fact that their act of taking photographs is not neither totally based on their intentionality nor absolutely connected to a spontaneous capture, but could be understood as placed somewhere in between. The architects' act of taking photographs is neither totally instrumental nor absolutely spontaneous. This in-betweenness to which I refer makes the photographs that the architects take while travelling by car a terrain or a nexus able to reveal the concreteness of their thought and their design strategies.

Despite the fact that John Lautner, Alison and Peter Smithson and Aldo Rossi shared their interest in taking photographs from the car and conceived the practice of taking photographs while travelling by car as a new method and tool for enriching their architectural and urban design strategies, their understanding of the impact of the automobile on architecture and their strategies of incorporating the problematics related to the car into their architectural practice differ.

In order to grasp the epistemological impact of the automobile on architectural and urban design practice, one should try to discern to what extent the stances of the architects under study vis-à-vis the view from the car differ. A way to understand to what extent they differ is to examine how they treat the concepts of seriality and sequentiality. Two characteristics of the perception of the city from the car that should be highlighted are its sequentiality or seriality and its capacity to promote a kinaesthetic experience of the urban landscape. Reyner Banham associated seriality with the capacity of series of photographs to provide a framework of understanding knowledge taxonomically (1988). This relationship of the seriality of the act of taking photographs to the idea of understanding knowledge taxonomically brings to mind the distinction that Rosalind Krauss draws, in "Photography's Discursive Spaces", between two forms of photographic meaning: one that is taxonomic and belonging to empirical space, another which is aesthetic and belonging to exhibition space (Krauss 1982).

The new theoretical framework that I suggest is based on two pairs of concepts: that between intentionality and causality; and that between stimulatory and documentary image. These two pairs of concepts can help us comprehend the way in which John Lautner, Alison and Peter Smithson and Aldo Rossi used the photos they took while travelling by car in order to build their conceptual and design approaches. A dilemma that emerges is that concerning the capacity of photography or film to more concretely capture the 'snapshot aesthetics' or 'auto-photographic grasp' referring to the act of taking photographs from the car. We could use the expression 'autophotographic grasp' is employed to describe the 'snapshot aesthetics' concerning the rapid, sequential and fragmentary perception of the urban territory from the car, which characterizes car travel.

The photographs that John Lautner, the Smithsons, and Aldo Rossi took during the journeys by car can serve as a terrain on which one can diagnose which aspects of an encountered landscape or building stimulated the aforementioned architects' interest. Through the classification of repeated and re-iterated motives and patterns that appear throughout their series of photographs, one can discern themes that dominated their thought and were present during different journeys. In parallel, these photographs can help us decipher how the architects 'read' the landscape and how a specific vision that is characteristic for each of these architects was transposed in the way they conceived and designed their own projects.

A meeting point of John Lautner, Alison and Peter Smithson and Aldo Rossi's approach is the elaboration of a 'snapshot aesthetics' that aims to capture contemporary urban life in its ordinariness and banality. Despite the fact that they shared their interest in taking photographs from the car and conceived this practice as a new method and tool for enriching their architectural and urban design strategies, their understanding of the impact of the automobile on architecture and their strategies of incorporating the problematics related to the car into their architectural practice differ. A way to understand to what extent they differ is to examine how they treated the concepts of seriality and sequentiality. Some characteristics of the perception of the landscape from the car that should be highlighted are its sequentiality, its seriality, or seriality and its capacity to promote a kinaesthetic experience. Reyner Banham associated seriality with the capacity of series of photographs to provide a framework 
of understanding knowledge taxonomically (Banham 1988). The act of producing taxonomies of the photographs retrospectively is related to two modes of seeing at stake when confronted with photographs that Dominic McIver Lopes highlights, in The Four Arts of Photography: An Essay in Philosophy (Lopes 2016), and Diarmuid Costello analyses further, in his book entitled On Photography: A Philosophical Inquiry: 'clear seeing' and 'defamiliarized seeing. The former mode of seeing mentioned by Lopes implies "focusing attention on features that are easily overlooked when seen directly", while the latter is related to the process of "estranging the appearance of everyday objects or scenes" (Costello 2017, p. 66).

As Robert Frank and Walker Evans road photographs trigger a sequential reading in the sense that they invite their interpreter to perceive them in taxonomies, John Lautner, Alison and Peter Smithson and Aldo Rossi's photographs do the same, but in a more complex way. This complexity lies in the fact that apart from relating the photographs among them in order to grasp their very meaning, one when encountered with the aforementioned architects' photographs is invited to relate them to their design strategies given that for them, the photographs played an instrumental role in shaping their design tactics. The concept of dispositif and its intention to enhance a dynamic understanding of the connections among the different parameters that constitute a system is compatible with such a reading of photographs. An understanding of photographs and drawings as dispositifs implies the acknowledgement of the fact that the interacting forces are in a continuous state of becoming. For this very reason, it seems as an efficient interpretation mechanism for analysing the exchanges between the architects' photography strategies and their design strategies.

\section{Acknowledgements}

I would like to thank the ETH Zurich Postdoctoral Fellowship programme and the Stavros Niarchos Foundation for their support. I am also thankful to Prof. Dr. Avermaete, the anonymous reviewers, and the editor of City, Territory and Architecture for their enriching comments.

\section{Authors' contributions \\ The author read and approved the final manuscript.}

\section{Author information}

Dr. ir. Marianna Charitonidou is a registered architect, spatial designer, curator, educator and architecture and urban design theorist and historian. She is a Lecturer and a Postdoctoral Research Fellow at the Chair for the History and Theory of Urban Design of the Institute for the History and Theory of Architecture (gta) of ETH Zürich, where she works on her project "The Travelling Architect's Eye: Photography and the Automobile Vision". Dr. ir. Charitonidou is the curator of the exhibition entitled "The View from the Car: Autopia as a New Perceptual Regime" (https://viewfromcarexhibition.gta.arch.ethz.ch) at ETH Zurich (5 March-15 October 2021). She is also Postdoctoral Research Associate at the School of Architecture of the National Technical University of Athens. In 2018, she was awarded a Doctoral Degree all'unanimità from the National Technical University of Athens for her PhD dissertation "The Relationship between Interpretation and Elaboration of Architectural Form: Investigating the Mutations of Architecture's Scope". She also holds a MPhil in History and
Theory of Architecture from the School of Architecture of the National Technical University of Athens (2013), a Master in Science in Sustainable Environmental Design from the Architectural Association in London (2011), and a Master in Architectural Engineering at the Aristotle University of Thessaloniki (2010). She was a Visiting Research Scholar at Columbia University's Graduate School of Architecture, Planning and Preservation (invited by Prof. Bernard Tschumi) and the Institute of Fine Arts of New York University (invited by Prof. JeanLouis Cohen), and the École française de Rome and resident at the Canadian Centre for Architecture (CCA) for her project "The modes of representation of Peter Eisenman, John Hejduk, Aldo Rossi and Bernard Tschumi: the 'observer' vis-à-vis the strategies of decodification". She has presented her research at more than 65 international conferences and has publishednumerous articles and chapters in scientific peer-reviewed journals and edited. In 2021, she was awarded Bruno Zevi Prize. She is the founder and principal at Think Through Design Architectural and Urban Design Studio. Among her publications are: "Frank Gehry's Self-Twisting Uninterrupted Line: Gesture-Drawings as Indexes", in Arts 10(1) (2021), "Housing Programs for the Poor in Addis Ababa: Urban Commons as a Bridge between Spatial and Social", in the Journal of Urban History (2021), "Simultaneously Space and Event: Bernard Tschumi's Conception of Architecture", in ARENA Journal of Architectural Research, 5(1)(2020), "The Immediacy of Urban Reality in Postwar Italy: Between Neorealism and Tendenza's Instrumentalization of Ugliness", in Architecture and Ugliness: AntiAesthetics and the Ugly in Postmodern Architecture (eds. Wouter Van Acker, Thomas Mical, Bloomsbury Press, 2020), "Music as a Reservoir of Thought's Materialization: Between Metastaseis and Modulor", in Aberrant Nuptials: Deleuze and Artistic Research 2 (eds. Paulo de Assis, Paolo Giudici, Leuven University Press, 2019), "Le récit autobiographique d'Aldo Rossi: Introspection ou rétrospection?", in L'Homme \& la Société 2018/3 (n²08), "Archives of Architecture Museums: The Effects of Digitisation", in OASE 99 (2017), "Réinventer la posture historique : les débats théoriques à propos de la comparaison et des transferts", in Espaces et Sociétés 2016/4 (n 167), "L'AUA entre le Team 10 et le postmodernisme", in Une architecture de l'engagement: I'AUA 1960- 1985 (eds. Jean-Louis Cohen, Vanessa Grossman, La Découverte/Cité de l'architecture et du patrimoine, 2015).

\section{Funding}

The research on which this paper is based received support from the ETH Zurich Postdoctoral Fellowship programme and the Stavros Niarchos Foundation.

Availability of data and materials

Not applicable.

\section{Declarations}

Competing interests

The authors declare that they have no competing interests.

\section{Author details}

${ }^{1}$ Chair of the History and Theory of Urban Design, Institute for the History and Theory of Architecture (gta), Department of Architecture, ETH Zürich, Stefano-Franscini-Platz 5, 8093 Zurich, Switzerland. ${ }^{2}$ School of Architecture, National Technical University of Athens, 42 Patission Street, 10682 Athens, Greece. ${ }^{3}$ Faculty of Art History and Theory, Athens School of Fine Arts, 42 Patission Street, 10682 Athens, Greece.

Received: 13 December 2020 Accepted: 28 April 2021

Published online: 20 May 2021

\section{References}

Alcolea RA, Tárrago J (eds) (2011) Architects'journeys: building traveling thinking. GSAPP Books and T6, New York

Alexander S (1986) Robert Frank: a bibliography, filmography, and exhibition chronology 1946-1985. Tucson, Center for Creative Photography, University of Arizona, in association with the Museum of. Fine Arts, Houston

Alù G, Hills SP (2018) The travelling eye reading the visual in travel narratives. Stud Travel Writ 22(1):1-15

Agrest D (1979) The architecture of the city (interview with Aldo Rossi). Skyline 2(4):4-5 
Banham R (1955) The new brutalism. Archit Rev 118(708):354-361

Banham R (1988) The becher vision. In: Bernd B, Hilla B (eds) 1988: water towers. The MIT Press, Cambridge, pp 7-8

Banham R (2009) Los Angeles: the architecture of four ecologies (1971), forward by Joe Day, introduction by Anthony Vidler. Berkeley: University of California Press

Barthes R (1972) The New Citroën. In: Mythologies (1957), trans Annette Lavers. New York, Hill and Wang

Bate D (2003) Photography and surrealism: sexuality, colonialism and social dissent. I.B. Tauris, New York

Borden I (2013) Drive: journeys through film, cities and landscapes. Reaktion Books, London

Boyer CM (1996) The city of collective memory: its historical imagery and architectural entertainment. The MIT Press, London

Brougher Ket al (2001) Open city: street photographs since 1950. Museum of Modern Art Oxford Hatje Cantz Verlag, Oxford, p 2001

Buse P (2016) The camera does the rest: how polaroid changed. University of Chicago Press, Chicago

Campany D (2014) The open road: photography \& the American road trip. Aperture Foundation, New York

Celant G (ed) (1969) Art povera. Praeger, New York

Charitonidou M (2020) Architecture's addressees: drawing as investigating device. Villardjournal 2:91-111 . https://doi.org/10.2307/j.ctv160btcm.10

Charitonidou M (2021) Frank Gehry's self-twisting uninterrupted line: gesturedrawings as indexes. Arts. https://doi.org/10.3390/arts10010016

Clifford J (1997) Routes travel and translation in the late twentieth century. Harvard University, Cambridge

Colomina B (2004) Unbreathed air 1956. Grey Room 15:28-59

Constantini, P (1996) Things Which Are Only Themselves. In P Costantini (ed) Luigi Ghirri/Aldo Rossi: things which are only themselves. Canadian Centre for Architecture, Electa, Montreal, Milan, pp 8-15

Costello D (2017) On photography: a philosophical inquiry. Routledge, London; New York

Court E (2016) Off the beaten track: Jack Kerouac on Robert Frank. MoveableType 8:24-33

Coward C (ed) (2017) Nigel Henderson's streets: photographs of London's East End 1949-53. Tate Publishing, London

Dal Co F (ed) (2000) Aldo Rossi: I quaderni azzurri. Getty Publications, Electa, Los Angeles

Deleuze G (1992) What is a dispositif? In: Armstrong TJ (ed) Michel Foucault, Philosopher. Harvester Wheatsheaf, Hemel Hempstead, pp 159-167

Deleuze G (2006) The Fold Leibniz and the Baroque, trans. Tom Conley (1988) London, Continuum

Ed Ruscha (1966) Every building on the sunset strip, self-published book, offset litho-graph (second printing 1971)

Eisenman P (1982) The houses of memory: the texts of analogue. In: Rossi A (ed) The architecture of the city, translated by D. Ghirardo and J Ockman. The MIT Press, Cambridge, Massachusetts, pp 3-11

Emerling J (2013) Photography: history and theory. Routledge, London

Esperdy G (2019) American autopia: an intellectual history of the American roadside at midcentury. University of Virginia Press, Virginia

Foucault M (1980) Power/knowledge. Selected interviews and other writings 1972-1977. In: Gordon C (ed),translated by C Gordon, L Marshall, J. Mepham, Kate Soper Pantheon Books, New York

Frank R (1958) The Americans. Robert Delpire, Paris

Frank R (1959) The Americans. Steidl, New York

Friedlander L (2010) America by car. Distributed Art Publishers, New York

Gannon T (2017) Reyner Banham and the paradoxes of high tech. With an unpublished essay by Reyner Banham. The Getty Research Institute, Los Angeles

Greenough S, Frank R, Alexander S (2009) Looking in: Robert Frank's The Americans. National Gallery of Art, Washington

Halbwachs M (1950) La mémoire collective. Les Presses universitaires de France, Paris

Halbwachs M (1992) On collective memory, trans Lewis A. Coser. University of Chicago Press, Chicago

Higgott, A (2012) Memorability as image: the New Brutalism and photography. In: A Higgott, TWray (eds) Camera constructs photography, architecture and the modern city. Ashgate, Burlington, VT, pp 283-294

Higgott A, Wray T (eds) (2012) Camera constructs photography, architecture and the modern city. Ashgate, Burlington

Jasper M (2017) Deleuze on art: the problem of aesthetic constructions. Cambridge Scholars Publishing, Newcastle upon Tyne
Jencks C, Baird G (eds) (1969) Meaning in architecture. Barrie \& Jenkins, London

Krauss R (1982) Photography's discursive spaces. Art J 42(4):311-319

Laine CK, Rossi A (1979) The work of Aldo Rossi. Crit 5:22

Laskey ML (1986) Responsibility, infinity, nature: UCLA oral history transcript. Regents of the University of California, Los Angeles, pp 15-19

Leach A (2015) Leaving Las Vegas, again. Grey Room 61:6-33

Leed EJ (1991) The mind of the traveler: from gilgamesh to global tourism. Basic Books, New York

Lewis DL, Rauhauser B (1996) The car and the camera: The Detroit School of Automotive Photography Detroit Institute of Arts. Wayne State University Press, Detroit

Lichtenstein C, Schregenberger T (2001) As found: a radical way of taking note of things. In: Lichtenstein C, Schregenberger T (eds) As found, the discovery of the ordinary: British architecture and art of the 1950s. Baden, Lars Müller, pp $8-10$

Lopes DM (2016) The four arts of photography: an essay in philosophy. WileyBlackwell, Oxford

Massey A (1995) The Independent Group: modernism and mass culture in Britain 1945-1959. Manchester University Press, Manchester

Mitchell WJT (1986) Iconology: images, text, ideology. University of Chicago Press, Chicago

Olsberg N (ed) (2008) Between earth and heaven: the architecture of John Lautner. Rizzoli International Publications, New York

Papageorge T, Evans W, Frank R (1981) An essay on influence. Yale University Art Gallery, New Haven

Perkins HC (2001) Gazing or performing? Reflections on Urry's tourist gaze in the context of contemporary experience in the antipodes. Int Sociol 16(2):185-204

Risselada M (ed) (2017) The space between: Alison and Peter Smithson. Verlag der Buchhandlung Walther konig, Cologne

Robbins D (ed) (1990) The independent group: Postwar Britain and the aesthetics of plenty. The MIT Press, Cambridge

Robertson H, Rowland F (1989) Travels in modern architecture 1925-1930. Architectural Association, London

Rosa J et al (1991) John Lautner: architect, Los Angeles: an exhibition on the occasion of his 80th birthday (exhibition catalog). Alvensleben, Vienna

Rossbacher P (1977) Šklovskij's Concept of Ostranenie and Aristotle's Admiratio. MLN 92(5):1038-1043

Rossi A (1966) L'architettura della città. Padova, Marsilio

Rossi, A (1979a) The architecture of the city (interview with Agrest D). Skyline 2(4):4-5

Rossi A (1979b) The meaning of analogy in my last projects, trans N Galetta. In: Solitary travelers. The Cooper Union School of Architecture, New York

Rossi A (1982) The architecture of the city, trans. Diane Ghirardo, Joan Ockman. The MIT Press, Cambridge

Rossi A (1996) For Luigi Ghirri. In: Costantini P (ed) Luigi Ghirri/Aldo Rossi: things which are only themselves. Canadian Centre for Architecture, Electa, Montreal, Milan.

Scalbert I (2018) A real living contact with the things themselves: essays on architecture. Park Books, Zurich

Scott Brown D (1984) Learning from pop. In: Venturi R, Scott Brown D (eds) The view from the Campidoglio. Selected essays 1953-1984. Harper \& Row, New York, pp 28-31. Originally published in Casabella, nos 359-360 (1971): 15-23

Scruton R (1981) Photography and representation. Crit Inq 7(3):577-603

"Signals That Think as Well as Blink", Los Angeles Times, 25 February 1960

Sklovskij V (1925) 0 teorii prozy. Moscow-Leningrad

Smithson A (1983) AS in DS: an eye on the road. Delft University Press, London

Smithson A (2001) AS in DS: an eye on the road. Lars Muller Verlag, Baden

Smithson A, Smithson P (1955) New brutalism. Archit Des 25(1):1

Smithson A, Smithson P (2001) The "As Found" and the "Found". In: Lichtenstein C, Schregenberger $T$ (eds) As found, the discovery of the ordinary: British architecture and art of the 1950s. Baden, Lars Müller

Stierli M (2013) Las Vegas in the rearview mirror: the city in theory, photography, and film. Getty Research Institute, Los Angeles

Storr R (1998) Tony Smith: architect, painter, sculptor. Museum of Modern Art, New York

Terranova CN (2014) Automotive prosthetic: technological mediation and the car in conceptual art. University of Texas Press, Austin

Tihanov G (2005) The politics of estrangement: the case of the early Shklovsky. Poetics Today 26(4):665-696 
Trachtenberg A (1989) Reading American photographs: images as history: Mathew Brady to Walker Evans. Hill and Wang, New York

Traganou J (2016) For a theory of travel in architectural studies. In: Mitrasinovic M, Traganou J (eds) Travel, space, architecture. Ashgate, Burlington, pp 4-26

Urry J (1990) The tourist gaze: leisure and travel in contemporary societies. Sage Publications, London

Urry J (2007) Mobilities. Polity, Cambridge

Urry J, Larsen J (2011) The tourist gaze 3.0. Sage Publications, London

Venturi R, Scott Brown D, Izenour S (1972) Learning from Las Vegas. The MIT Press, Cambridge, Mass

Virilio P (1995) The art of the motor, trans. Julie Rose. University of Minnesota Press, Minneapolis

Virilio P (1998) Dromoscopy, or the ecstasy of enormities. trans. Edward R. O'Neill. Wide Angle 20, 3:10-22
Wagstaff SJ Jr (1966) Talking with Tony Smith. Artforum 5(4):14-19

West Brett D (2016) Photography and place: seeing and not seeing Germany after 1945. Routledge, London

Yoder J (2014) Vision and crime: the cineramic architecture of John Lautner. In: D Medina Lasansky (ed) Archi.Pop: Mediating architecture in popular culture. Bloomsbury Academic, London, pp 45-58

\section{Publisher's Note}

Springer Nature remains neutral with regard to jurisdictional claims in published maps and institutional affiliations.

\section{Submit your manuscript to a SpringerOpen ${ }^{\circ}$ journal and benefit from:}

- Convenient online submission

- Rigorous peer review

- Open access: articles freely available online

- High visibility within the field

- Retaining the copyright to your article

Submit your next manuscript at $\boldsymbol{\nabla}$ springeropen.com 